\title{
Communication Measures to Bridge Ten Millennia
}

\author{
Technical Report
}

April 1984

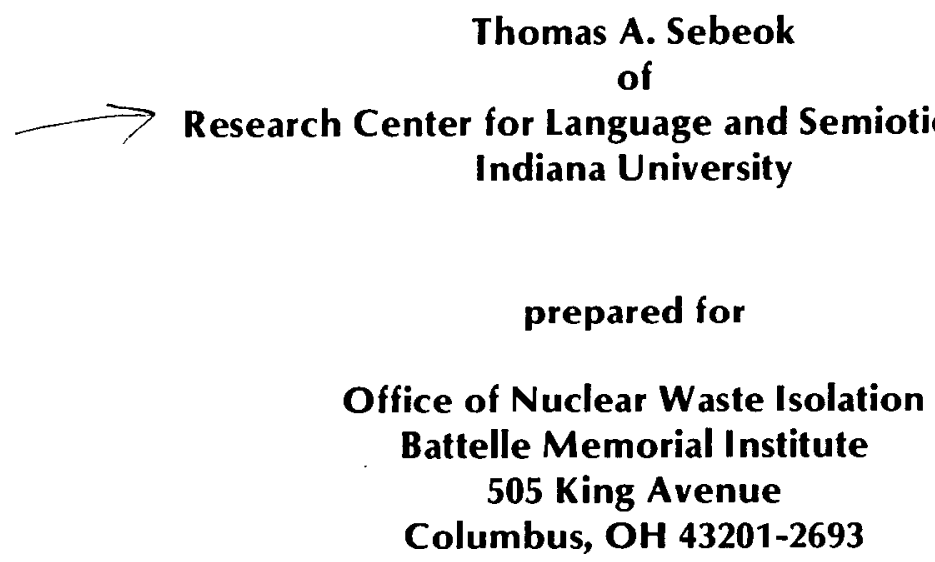

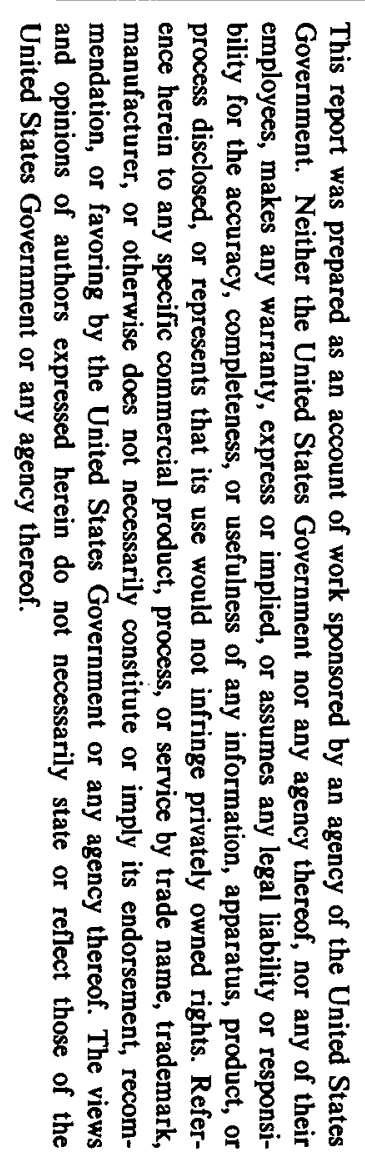

The content of this report was effective as of September 1981. This report was prepared by Research Center for Language and Semiotic Studies, Indiana University under Subcontract E512-01600 with Battelle Project Management Division, Office of Nuclear Waste Isolation under Contract No. DE-AC02$83 \mathrm{CH} 10140$ with the U.S. Department of Energy.

This document is PUBLICLY RELCASABLE ham E Qvillians 


\section{DISCLAIMER}

This report was prepared as an account of work sponsored by an agency of the United States Government. Neither the United States Government nor any agency Thereof, nor any of their employees, makes any warranty, express or implied, or assumes any legal liability or responsibility for the accuracy, completeness, or usefulness of any information, apparatus, product, or process disclosed, or represents that its use would not infringe privately owned rights. Reference herein to any specific commercial product, process, or service by trade name, trademark, manufacturer, or otherwise does not necessarily constitute or imply its endorsement, recommendation, or favoring by the United States Government or any agency thereof. The views and opinions of authors expressed herein do not necessarily state or reflect those of the United States Government or any agency thereof. 


\section{DISCLAIMER}

Portions of this document may be illegible in electronic image products. Images are produced from the best available original document. 


\section{DO NOT MICROFILM \\ THIS PAGEFLockaphIC Data}

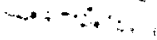

Sebeok, Thomas A., 1984. Communication Measures to Bridge Ten Millennia, BMI/ONWI-532, prepared by Research Center for Language and Semiotic Studies, Indiana University, for Office of Nuclear Waste Isolation, Battelle Memorial Institute, Columbus, $\mathrm{OH}$.

\section{NOTICE}

This report was prepared as an account of work sponsored by an agency of the United States Government. Neither the United States Government nor any agency thereof, nor any of their employees, makes any warranty, expressed or implied, or assumes any legal liability or responsibility for the accuracy, completeness, or usefulness of any information, apparatus, product, or process disclosed, or represents that its use would not infringe privately owned rights. Reference herein to any specific commercial product, process, or service by trade name, trademark, manufacturer, or otherwise, does not necessarily constitute or imply its endorsement, recommendation, or favoring by the United States Government or any agency thereof. The views and opinions of authors expressed herein do not necessarily state or reflect those of the United States Government or any agency thereof.

Printed in the United States of America Available from

National Technical Information Service

U.S. Department of Commerce

5285 Port Royal Road

Springfield, VA 22161

NTIS price codes

Printed copy: $\mathrm{A03}$

Microfiche copy: A01 
The Department of Energy created the Human Interference Task Force (HITF) in 1980 to investigate the problems connected with the postclosure, final marking of a filled nuclear waste repository. The task of the HITF is to devise a method of warning future generations not to mine or drill at that site unless they are aware of the consequences of their actions. Since the likelihood of human interference should be minimized for 10,000 years, an effective and long-lasting warning system must be designed. This report is a semiotic analysis of the problem, examining it in terms of the science or theory of messages and symbols. Because of the long period of time involved, the report recommends that a relay system of recoding messages be initiated; that the messages contain a mixture of iconic, indexical, and symbolic elements; and that a high degree of redundancy of messages be employed. 


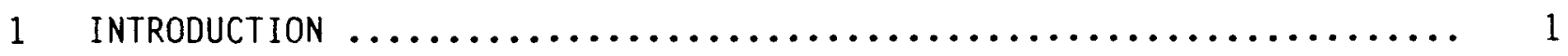

2 SOME BASIC PRINCIPLES OF SEMIOTICS $\ldots \ldots \ldots \ldots \ldots \ldots \ldots \ldots \ldots \ldots \ldots \ldots \ldots \ldots$

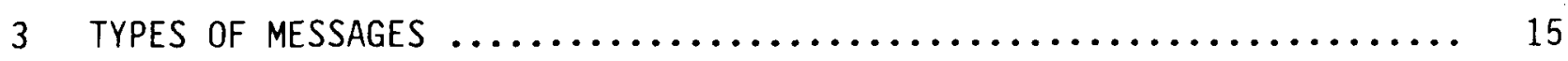

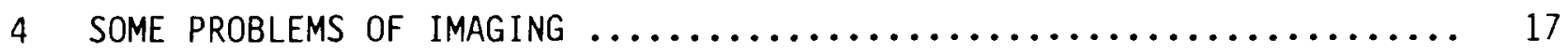

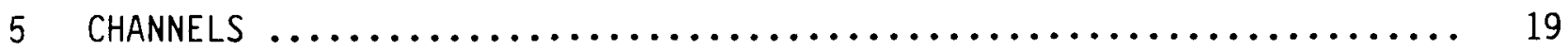

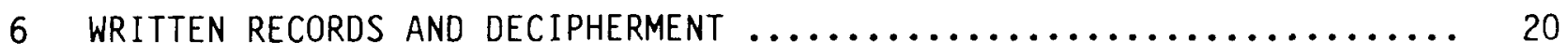

7 RECOMMENDATIONS (AND RELATED CONSIDERATIONS) $\ldots \ldots \ldots \ldots \ldots \ldots \ldots \ldots . \ldots \ldots$

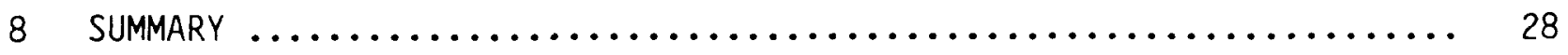

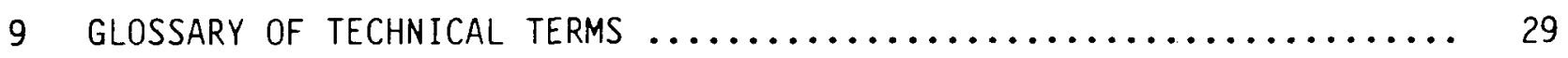

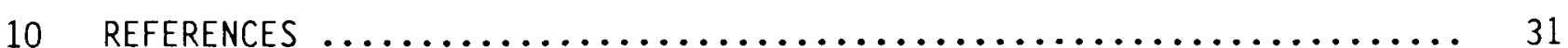

\section{LIST OF FIGURES}

Figure 1. Basic Elements of Communication $\ldots \ldots \ldots \ldots \ldots \ldots \ldots \ldots \ldots . .6 \ldots$

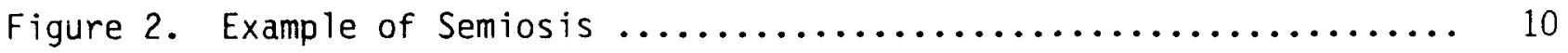

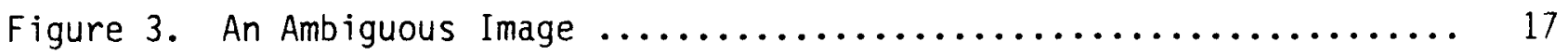

Figure 4. Engraving by Giulio Bonasone, "Man's Opening the Fateful Vesse1" (Between 1531-1574) ................ 22

Figure 5. Gouache by Max Beckman, "Pandora's Box"

(Begun in 1936, but thoroughiy repainted in 1947) .......... 23 
Any viable strategy for radioactive (hazardous) waste disposal, in which the repository would be situated in a rock mass beneath a blanket of sedimentary rocks whose physical characteristics are well understood, entails the possibility of human intrusion, which must and can be minimized. For any repository situated in a geological medium, all sorts of natural and engineered barriers can be brought into play to act to prevent migration of the wastes, such as "( $i$ ) the waste form and its capsule; ( $i$ ) engineered barriers within the repository, such as low-permeability, highly sorptive backfill; and ( $i i i$ ) the migration path back to the biosphere through the ground-water flow system" (Bredehoeft and Maini, 1981:296); and others (e.g., Winograd, 1981). A "barrier" is commonly defined as a mechanism or medium by which the movement of emplaced radioactive material is stopped or retarded significantly.

Those barriers will be effective in decreasing both the likelihood and potential consequences of radioactive material releases. Human interference is one of the potential mechanisms that could lead to such releases. One mechanism to decrease the likelihood of human interference is a requirement by the Nuclear Regulatory Commission in its regulation, 10 CFR 60 (U.S. Nuclear Regulatory Commission, 1983), which requires permanent markers and records for waste repositories to warn potential intruders of what is there. The U.S. Department of Energy, anticipating the final closure of a completed repository, and recognizing the requirement for a warning system, has set up the Human Interference Task Force through the Office of Nuclear Waste Isolation. This paper is part of the study of the Task Force. It deals with semiotic techniques designed to restrict, if not altogether prevent, access to the material. Since the objective is to minimize the possibility of future human intrusion at the site, a disposal strategy needs to be developed that takes cognizance of the soundest knowledge currently available in the field of General Semiotics.

Semiotics is the name of the discipline which brackets the conjoint scientific study of both verbal and averbal systems of communication. It is thus focally relevant to the problems of human interference and message exchanges involving long periods of time, over which spoken and written languages are sure to decay to the point of incomprehensibility, making it 
necessary to utilize a perspective that goes well beyond linguistics (the formal study of verbal messages), which, traditionally (mainly in the 19th century), has dealt with the relatively brief diachronic past, or (mainly in the 20 th century) the synchronic present. Workers in semiotics, or in its narrower branch called linguistics, have very seldom been called upon to make projections into the short-range future, let alone the long-range future, which, in the case at hand, must take into account up to 10,000 years, or (according to current actuarial calculations), the span of 300 generations to come.

It is generally believed that the "social function of communcation is the ensuring of continuity in society through access to the experiences and ideas of the past, expressed in [loosely speakingl symbols for transmission across space and through time. This is the 'time-binding' function of social communication" (Neelameghan, 1979:103). The time-binding ability of human beings arises from their usage of "language, number, gesture, picture, and other symbolic forms" (10c. cit.) enabling them to transcend the limitations of inherited characteristics and the seemingly insurmountable barrier of "time". It should be noted, in passing, that an era will come when messages vitally important to the race, affecting its survival, will be transmissible by microsurgical intervention with the human molecular blueprint, but the technology required for this form of temporal communication is far from available as yet. Therefore, in what follows, this theoretical possibility will not be further considered. 


\section{SOME BASIC PRINCIPLES OF SEMIOTICS}

*Semiotics, 1 the pivotal branch of the integrated science of communication (Jakobson, 1970:33), is concerned with the formulation and encoding of messages by *sources, the transmission of these messages through *channels, the *decoding and *interpretation of these messages by *destinations, and their *signification. The entire transaction, or *semiosis, takes place within a *context to which the system is highly sensitive and which the system, in turn, affects. Any living entity, or its products, can be either message sources or destinations.

Humans are unique in being able to process both verbal and averbal messages. Semiosic acts are monitored by *feed mechanisms (Bogart, 1980), which can variously function to fine-tune performances. Differences between input and output are due to *noise", which can, however, be counteracted by * "redundancy". The process of message interchanges, or *semiosis, is held by many to be an indispensable characteristic of all terrestrial life forms. It is this capacity for containing, replicating, and expressing messages, of extracting their significance, that, in fact, distinguishes them more consistently from the nonliving -- except for human agents, such as robots, that can be programmed to engage in quasi-semiosis -- rather than other traits often cited, such as the ability to reproduce (e.g., mules or neutered cats do act as message sources and destinations, but none can reproduce).

All human messages fall into two distinct categories: *verbal messages and *averbal messages. *Language -- as the array of verbal messages is collectively referred to -- has, so far, been found only in our own species; biologists would thus say that language constitutes a "species-specific" trait. The study of this unique yet "species-universal" attribute of human beings, their language, is the subject matter of *linguistics, which is one of the most sophisticated, partially formalized branches of semiotics. The rich repertoire of averbal messages of human beings-- by sharp contrast with their language -- has not comprised a unified field of study, and therefore lacks a

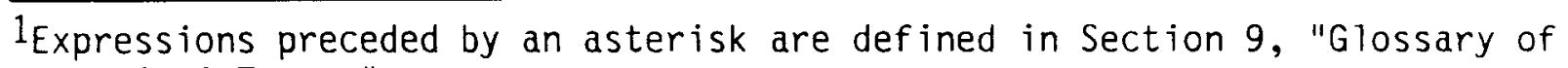
Technical Terms." 
positive integrative label. Averbal messages are, by definition, not linguistic. This negative delineation has led to terminological chaos, which is manifoldly compounded when the multifarious message systems employed by the millions of speechless creatures are additionally taken into account.

Averbal messages can be distinguished from one another according to several criteria of semiotic relevance. Let me briefly illustrate this point by going back to a classic discussion found in the Hippocratic writings on medical semiotics, where sēmeion -- from the same root as both * semiotics" and * "semiology" -- is used to refer to the observable "symptoms" by which a physician identifies a disease ("makes a diagnosis") and forecasts its outcome ("makes a prognosis") (Miller, 1979:44). This standpoint of Hippocrates (ca. 460 - ca. 377 B.C.) -- whom historians have sometimes reverentially regarded as "the father and master of all semiotics" -- hinges on an ancient but still widely prevalent distinction drawn between two kinds of messages: "conventional" vs. "natural".

*Conventional messages are those whose power to signify is thought to depend on some prior agreement, presumed to have been reached at some temporal juncture, and thereafter accepted as a matter of custom -- such as, most important $1 y$, messages cast in spoken or written utterances, but also frequently messages that are embodied in the shape of a parochial gesture, a tradition exercised and understood by one group of persons but not necessarily by their neighbors. The meaning of a conventional message -- whether verbal or not -- is invariably circumscribed to a time and place.

So-called *natural messages, on the other hand, have the power to signify the same things at all times and in a 11 places, precisely because their interpretation does not presuppose a familiarity with the conventions of a particular group. For this reason, "natural messages", as here defined, are particularly pertinent to the present responsibility of the Human Interference Task Force.

After describing certain averbal symptoms (sēmeia), Hippocrates does go on to say, in his treatise on Prognostic, that these "prove to have the same significance in Libya, in Delos, and in Scythia". Given the quasiuniversality of the class of averbal messages physicians call symptoms, he does not deem it "strange that one should be right in the vast majority of instances, if one learns them well and knows how to estimate and appreciate them properly" (ibid:45; after Hippocrates's Prognostic Xxv). 
By contrast, what is sometimes designated as being a *multimessage", (i.e., a conventional gesture), is one that has a number of totally distinct meanings, the choice of interpretation depending on the time and the place. Thus all Americans are familiar with the raised hand gesture, performed in such a way that the thumb and forefinger form a circle. This essentially signifies that something is "OK". In other countries, however, the same configuration may mean something totally different: for example, in Japan, "money", in the South of France, "zero" or "worthless"; in many places it may convey an obscene comment or an insult, as it did in Greece more than two thousand years ago; again, in some other areas it may betoken nothing at all (Morris, 1977:39-40).

These examples illustrate a single feature by which human averbal messages are distinguishable in terms of their temporal or spatial distribution. Many others can be adduced.

It is convenient to begin a general preliminary consideration of messages where they are assumed to originate. Their inception can be pictured as being a box (see Figure 1, page 9), which I have already designated the *source. A message can now be provisionally defined as a selection out of a ${ }^{\star}$ code by a source. The concept of a code will be explained later, but it should immediately be noted that many of the rules of probability governing this selection are unknown.

The source box is nothing more than a formal model used for erecting hypothetical constructs: given a certain input, one must guess, more or less, at what takes place to account for the output. When psychologists speak of "black box", they assume that nothing is known about what is inside the organism or about the functioning, say, of the central nervous system. However, the correlations between input and output may enable certain inferences to be made, not about the mechanism inside the box but about how it works.

In semiotics, it is more accurate to postulate a source box that is not altogether black but falls in a twilight zone between ignorance and knowledge: that is, in some cases, we do know something about its workings, although obviously far from enough. In schematic terms, these complex operations can be divided into two successive processes: an early one so murky as to be hardly more than a vacuous label, and a later one gradually dawning into more or less sharp scientific focus. 
The first process is referred to as the *formulation (or generation) of the message. A source "formulates" a message, but precisely how any organism does so is not known and will remain enigmatic until the electrochemical machinery of the human and animal minds, in their immense complexity, is far better understood. Human beings, it seems reasonable to postulate, follow, by and large, generative rules to create an enormous number of novel messages appropriate to an indefinite variety of contexts, but how they are able to do this is still an utter mystery. Detailed charting of the highly intricate and continuously readapting pathways within the three-and-one-half-pound globe of tissue under the sku11 known as the human brain remains a task for the future. It is conceivable that other animals store in advance separate internal representations for each message produced for use in a limited set of environments, but this is also uncertain.

Were we to picture an organic source, as in Figure 1 , we would have to darken the leftmost portion to reflect our ignorance; here the box is opaque. If the source were engineered, say, a general purpose computer, we would be able to specify exactly how the mechanical system formulates its messages, since a human programmer has imperatively prescribed the action by a special coding operation: mapping the human multidimensional language into some artificial unidimensional language. However, the primary concern here is with tenebrous living primary sources, and only incidentally with translucent inorganic secondary artifacts.?

Engineers sometimes speak of two kinds of sources: discrete and continuous. A discrete source produces messages ("letters") selected out of an enumerable set of possibilities ("alphabet"); such a source might produce, for example, written English. A continuous source is one that is not discrete -say, one that produces spoken English or music.

In the communication disciplines, as throughout the life sciences, it is both legitimate and necessary to raise questions teleonomic in aspect. Accurijingly, it is now proper to ask: for what purposes do sources formulate

2The Human Interference Task Force can be considered as the "source" that is charged with the obligation to collectively formulate the message, or set of messages, for a future destination, i.e., a would-be intruder, or group of intruders, to the repository site. 
messages? The functions of messages are various. They are end-directed in the same objective sense in which all animal behavior has a goal: an animal ingests food to gain materials and energy; its digestive apparatus and enzymes exist and operate as they do in order to promote this goal of survival. Messages embody information biologically or socially important for organisms; they are formulated, among other reasons, in order to be "transferred" to another entity, here named the *destination.

It is convenient to think of the destination as a second box (or operational concept, or a model), the area at which the message fiow initiated by the source terminates. Its workings can be segmented into two temporally successive processes, the reverse of formulation: an early one, characteristics of which are more or less understood, and an ultimate one -- usually referred to as the *interpretation of the message -- the manner of which shades off into unfathomed dusk; in this case, the rightmost portion of the diagram (Figure 1) would have to be blackened.

The source is normally incapable of launching its message in the neuroelectro-chemical shape in which we surmise that it was initially formulated. The reason for this is that there is ordinarily no direct neuro-electrochemical passageway to the destination; each source is linked with each destination via some sort of medium, or *channel, a passageway through which the two are capable of establishing and sustaining the exchange. An example of a channel is the link postulated between a pair of communicating American Indians, in such a way that one, the source, moves a blanket over a fire, while the other, the destination, observes the resulting message cast, or coded, in smoke (a form of electromagnetic energy).

Any form of energy propagation can, in fact, be exploited for purposes of message transmission. The point to remember is that the message-as-formulated -- conceivably, in sinusoidal pattern components -- must next undergo successive transformations while progressing on its journey toward the destination. The transmissions are "handed on" from one relay station to the next, and, before reaching the primary projection area, they need to be rearranged -filtered and adjusted -- to suit the chosen channel. It is not known, specifically, how one part of the brain communicates with another, how the messages are constructed and stacked in a hierarchy, or how their meanings are "agreed to" (coded). Neurophysiologists surmise that, no matter what a messagr may 
correspond to in the external world, internally it is likely to be represented by nerve impulses linked by chemical exchanges, probably functioning synchronously in various regions, which may be closely adjacent to or quite remote from one another in the two-dimensional cortical sheet of higher animals, including humans.

The transformation from this unconscious parallel processing to an externalized serial string, as in speech, or writing, or gesturing, must be effected by surface organ systems -- in humans, e.g., the so-called organs of speech -- and this crucial *transduction is called *encoding. It happens at the interface between internal and external message systems, which, in a broad sense, stand in a specular relationship, in a homology of spatial and temporal transition probabilities. When the destination receives the encoded messages another transduction, followed by a series of further transformations, must be effected before this message can be interpreted; the pivotal reconversion is called *decoding.

"Transduction" refers to the neurobiological transmutation from one form of energy to another, such as a photon undergoes when impinging on the vertebrate retina: we know that it entrains impulses in the optic nerve that change rhodopsin (a pigment in the retinal rods of the eyes), through four intermediate chemical steps, from one state to another. A message is said to be "coded" when the source and the destination are "in agreement" on a set of transformation rules used in the exchange. Because of entropy (a measure of disorder in the system; see Rifkin, 1980), the message-as-encoded can never be identical with the message formulated and launched by the source.

The kind of code selected by the source depends crucially on the total sensory equipment at its disposal. It would be abortive for an animal that is dumb -- as the great majority of them are -- to broadcast acoustically coded messages to its own kind that may be deaf. Human sense organs are capable of registering only a small portion of ambient acoustic stimuli: thus we can normally cope only with frequencies between $\sim 16$ and $\sim 22,000$ hertz, and are, in this respect, surpassed by the smallest bat, every dog, many rodents, and countless other animals.

The range of seeing likewise differs considerably in various animals: humans, who are incapable of perceiving ultraviolet bordering on the $X$-ray region to about 100 Angstroms, which is readily distinguishable by the 
honeybee and other insects, will scarcely encode their messages in the -- to them -- invisible spectrum, which could be decoded by other humans only with special enhancing instrumentation. The same is true of infrared, which certain nocturnal mammals, possessing a special organ (the tapetum lucidum) causing reflected night eye-shine, can manage to communicate by "in the dark", as we cannot, save with the aid of recently developed technology.

An excursion into the field of sense organs will be necessary to understand the wide variety of codes utilized in the animal world and by humans to insure that reciprocal understanding is achieved. Messages are transmitted, through acoustic and optical channels, as well as through more or less unfamiliar ones; even the best known channels may play a crucial role in communication in ranges beyond the limits of normal (i.e., cognizant) human perception, and thus beyond normal awareness.

The following very general diagram (Figure 1) illustrates the main points made so far. This model is not to be regarded as a piecemeal assemblage of constituents that can be represented as the sum of the properties of its several parts; on the contrary, the process of semiosis indispensably requires that each constituent be conceived of as functioning in relation to every other.

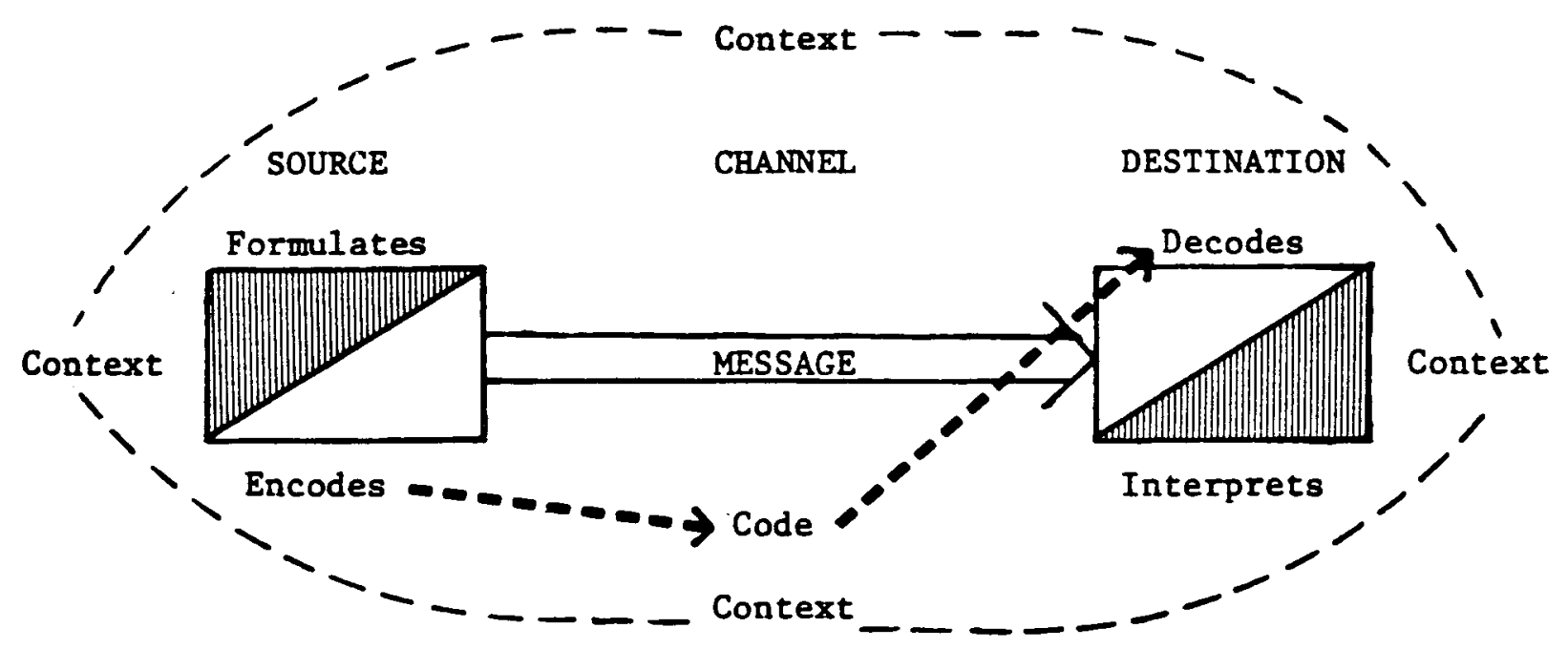

Figure 1. Basic Elements of Communication 
This diagram can be applied with many variations, to numberless concrete instances of semiosis, as, for instance, in Figure 2:

\section{Not all telephone cables are on poles.}

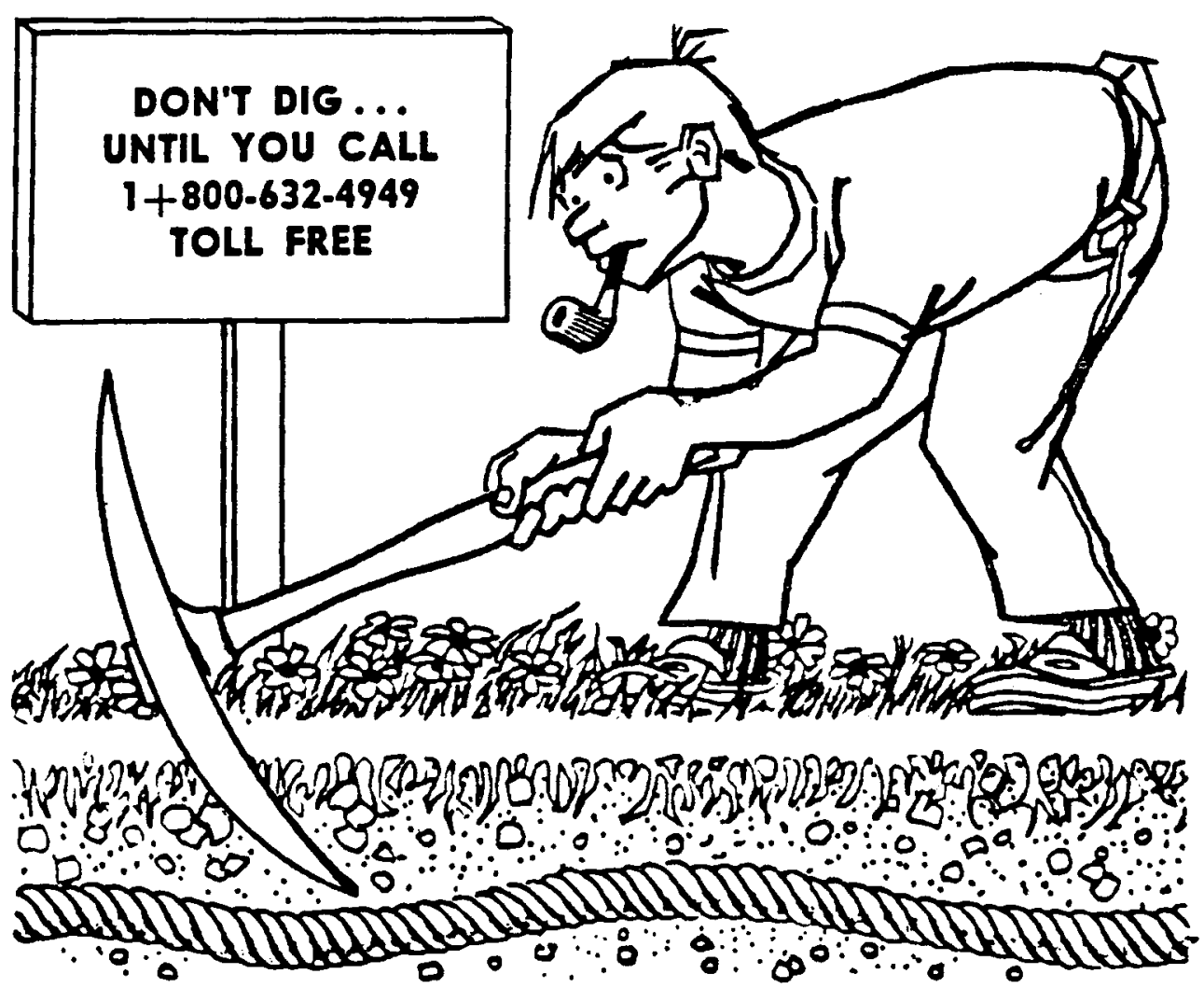

Many of them are underground. Out of the way and out of sight. And there may be one just where you're planning to dig that sewer, that foundation, or that well.

If you hit and damage telephone cable, everybody loses. Your job gets held up. We have to make repairs. People are deprived of some service and they get mad at both of us. It's so easy to avoid this kind of trouble. We'll check out the location in a jiffy and let you know where the cables are.

\section{Figure 2. Example of Semiosis}

(Reprinted by permission of General Telephone Company of the Southeast)

The source of the above message (Figure 2) -- i.e., the immediate source -- is the Durham, North Carolina, telephone directory for 1981. The ultimate source is the management of General Telephone, upon whose instructions the anonymous draftsman encoded the sketch to suit the text the 
management wanted to convey to the public, chiefly, that segment likely to engage in shallow digging. The message as a whole consists of a judicious mixture of verbal and averbal elements, which are meant to be mutually reinforcing, or, if the destination is assumed to be illiterate, at least partialiy significant by virtue of the pictorial element. Note that the design incorporates not only the message intended to be conveyed but also the metamessage (message about the message) that further information can be and should be obtained, without cost, according to such-and-such a procedure.

A very important component pictured in Figure 1 is the message *context, or setting, in which the entire transaction takes place. The context in which any message is emitted, transmitted, and admitted decisively influences its interpretation, and vice versa: the context of transactions is continually modified by the messages being interpreted; messages, in brief, are always more or less context-sensitive. This much is well known, but just how an organism takes its environment into account remains unclear.

The notion of "context" has been employed differently by various investigators, but, broadly speaking, the term refers to the organism's cognizance of conditions and manner of appropriate and effective use of messages. Context includes the whole range of the animal's cognitive systems (i.e., "mind"), messages flowing parallel, as well as the memory of prior messages that have been processed and, no doubt, the anticipation of future messages expected to be processed. Some semioticians have consigned the study of contexts to a nebulous subdivision of the field called "pragmatics" (complementing "syntactics" and "semantics"; see Morris, 1971, and Cherry, 1978, Appendix, pp. 339343). In the case of the telephone company's emblem (Figure 2), whatever context General Telephone's management deemed necessary for potential intruders to know is incorporated, in part, in the English legend printed underneath, and, in part, averbally, in the drawing itself.

Context is often the crucial factor in resolving the significance of a message. Thus messages encoded in the chemicals isovaleric acid and methyl mercaptan are components, respectively, of human body malodor and halitosis. This notwithstanding, the same chemicals and, consequently, the same odors, are responsible for some of the bouquet and flavor of cheese -- contexts account for the difference in interpretation. 
The verbal context may subtly yet decisively affect memory, as was shown in a remarkable experiment by Loftus (1980) and Palmer. These two psychologists showed a movie of an automobile accident, and questioned two different groups of "witnesses" about it in two slightly different ways. One group was asked, "How fast were the cars going when they smashed into each other?" The other group was asked, "How fast were the cars going when they hit each other?" A week passed. Then a11 "witnesses" were asked: "Did you see any broken glass in the accident?" Although there was no broken glass, those who were cued with the verb "smash" were more than twice as likely to erroneously report the presence of broken glass than those originally cued with the verb "hit".

The context often determines whether the destination will believe or disbelieve the message received. For instance, imagine a little boy running up to nis mother, exclaiming: "Mummy, Mummy, there is a tiger in the backyard." More likely than not, his mother will reply: "Johnny, stop making up stories!" Suppose, however, that the family lives in Venice, Florida, practically next door to the Winter Quarters of a famous circus which, the mother is fully aware, features a "Big Cats" act. The little boy's exclamation is more likely to be given credence than not.

The diagrams pictured in Figures 1 and 2 misleadingly suggest that the systems represented are static. All semiotic systems are, to the contrary, not only dynamic, but adaptive, that is, self-regulated to adapt both to the external context (conditions of environment) and the internal context (circumstances inherent within the system itself). At successive points, intelligence mechanisms come into play about system conditions which can, accordingly, activate and shape coping responses; their flow is commonly described as a *"feed process" (Bogart, 1980). Feed processes typically move, in mutually complementary fashion, forward as well as backward, forming loops. Thus the source normally checks whether the launched message stream reaches the destination according to expectation (*"feedforward"), whereas the destination tends to continually confirm or disconfirm this (*"feedback") to the source. *Feedforward is like a trend forecast that biases perception and enables the source to adjust its performance in anticipation of changefur happenings; in the favorable case, it may facilitate the avoidance of mistakes. *Feedback brings into the frame information about the working 
efficiency of the system itself -- information which is then "fed back" into the system, thus enabling adjustments on the basis of results accomplished.

An example of feedforward, taken from familiar organizational surroundings, is budgetary planning: the Vice-President for Research and Engineering (the source) tells a department manager (the destination) by a memo (the message) how much money the department, say, of the Apex Corporation, may spend during the coming year, and he then designs, or redesigns, the department's activities on the basis of this "foreknowledge". A different example: Many predators (the source) -- including various raptors, bats, wolves, lions, polar bears -- capture their prey (the destination) by a maneuver called "interception" (of the message). This means that the predator aims not at where the quarry is, but where it is most likely to be at the moment of impact, that is, a precise point ahead of the quarry in its calculated trajectory.

A common example of feedback comes from a habitual university setting. As I (the source) deliver a lecture (my message) to my class (the destination), I unintermittently monitor the students' fluctuating level of engrossment or tedium by way of their acoustic and optic messages broadcast to me, wittingly or unwittingly, via a feedback loop; conscientiously, I endeavor to attune my presentation in conformity with their expressions. A different example: my heartbeat (the source) is slowed or speeded by a complex of neural and humoral factors (the message) by the vagal and sympathetic cardiac efferents (channels); changes from the normal rhythm are reported (fed back) by sensitive interoceptors (other channels) to the brain (the destination), specifying factors such as timing, volume, and pressure of each pulse. This feedback loop between heart and brain provides an oscillatory input to my central nervous system on the basis of which vital readjustments can be effected.

The message received (and finally interpreted) by the destination is, in practice, seldom identical with the message sent (after being formulated) by the source; in other words, the output of the channel generally does not agree with its input. The discrepancy $M \hat{S} \neq M \hat{a}$, may be due to random and persistent disturbances that variously intrude into the system and obscure the clarity or quality of the message or, in extreme cases, obliterate its comprehension entirely. A channel might also, say, for secrecy, contain a cryptographic 
scrambling device. Such disarrangements, which make the output unpredictable even when the input is known, are called *noise. To circumvent noise and thereby to decrease the probability of transmission errors, the source habitualiy introjects *redundancy. There are many kinds of noise and many techniques for overcoming it, but always at a price -- as, for instance, slowing the source (and thus the entire transaction) down, or in other ways.

Imagine, for example, an airport traffic controller (the source) attempting to convey precise landing instructions (the message) to a pilot (the destination) by radio (the channel) during the electric storm (noisy environmental context). One means -- perhaps the simplest -- whereby the controller can introduce redundancy to insure reasonably error-free reception in such a high-risk situation is to reiterate all or parts of his original message, even at the expense of slowing him -- and the process of landing -- appreciably. After the delivery of every message-instance, the controller might ask (feedforward): "Do you copy?" The pilot will repeat what he understands his instructions to be (feedback). If he judges that a satisfactory consensus has been reached, he might so acknowledge with the code "Roger...", and conclude with "...out".

A different example: When I utter a sentence, $M \hat{1}$, in the presence of light, I simultaneously engage in a wide array of other bodily movements, $M^{2}, 3 \ldots n$, some of them audible ("paraphonetic"), most of them visible (avocal as well as averbal). $M 1$ and $M^{2}, 3 \ldots n$ are always partially redundant, a welcome fact which, under noisy conditions, reduces the degree of misunderstanding between the communicants. The force of this everyday example can be appreciated by turning off the sound on your television set, or, alternatively, by leaving on the sound but masking the image. Incidentally, geneticists have found that the relation between the nucleic acid code (a fourletter code) and the prote in code (a twenty-letter code) -- the genetic code -- is replete with natural redundancy, since several groups of three nucleotides, or triplets, along the nucleic acid chain, define the same amino acids along the protein chain (i.e., these groups are synonymous). Some amino acids have as many as six codons; Jacob (1965:25) has commented on their abundance in the inventory of synonymous triplets: "...redundancy gives a certain suppleness to the script of heredity." 


\section{TYPES OF MESSAGES}

We have already seen that human beings are capable of dual means of communication: verbal and averbal. These are, in daily practice, intimately intertwined, and either mutually redundant, reinforcing, or, as the case may be, contradictory.

Another classification cross-cuts the above. Message types -- ideally conceived -- are either *iconic, or *indexical, or *symbolic. In actuality, most messages are a combination of two or all three aspects, stacked in a contextually appropriate hierarchy, which shifts over time as the context aiters. Every natural language consists of a complex interplay of subtly shifting iconic, indexical, and symbolic signs (Jakobson 1965:26).

An iconic message is one which resembles -- according to some conventionally accepted criteria -- some segment of the real world to which it refers. When Julius Caesar said: "Veni, vidi, vici" ("I came, I saw, I conquered"), the order of the three verbs he used iconically represented the order of his three successive actions in Gaul. This is an example of verbally expressed syntactic iconicity.

Images, such as drawings or photographs, are commonly utilized icons in our culture: there is an assumed isomorphism between the pictorial representation and the thing represented. An example is our Star Spangled Banner: what is iconic about the United States flag is the fact that each of the fifty white stars in a single blue canton "stands for" one of the fifty states in the present Union, whereas each of the thirteen stripes "stands for" one of the Colonies that originally formed the Union (Sebeok, 1976:121). The important point here is that their iconic relations can be grasped only by those already informed of the code, or convention (viz., American history) being used. There are other aspects of our flag which are indexical and symbolic; the aspect that predominates is always a function of the context. An indexical message is one which "points to" an object or is a sample of it. Verbal indexes are, for one set of examples, all pronouns: "I" means "me" when I utter it; but when Ronald Reagan utters the same combination of phonemes, they add up to "Ronald Reagan". "Today" means "Monday" as I am writing this sentence; had I written it yesterday, "today" would have meant "Sunday". If I place onto a marker a tiny box containing radioactive waste 
from a nuclear power plant, this would (in that context) be an index of a large quantity of waste resulting from reprocessed spent fuel in the vicinity -say, encapsulated in a canister sunk far beneath the surface sample.

A symbolic message is one whose relationship to the "state of affairs" that it purports to represent is arbitrary, that is, understandable because of a preexisting social convention which specifies that the message will, to all who concur, stand for thus-and-so. For instance, the spoken word "dig" will be understood by all who are privy to the code known as "modern spoken English" as, roughly, equivalent to "excavate" (and associated notions), given the right context; (in other contexts, the same morpheme might mean "thrust", "reside", "poke", "apprehend", "enjoy", and so forth -- derivative extensions commonly called "metaphoric meanings"). Symbols, of course, can be encoded in various other modalities. The American flag is also a symbol triggering deep emotional responses -- say, in the context of a burial at Arlington National Cemetery.

The technical word used for highly formalized symbols in the visual mode is * "emblem"; examples of emblems are the international symbol used to inform of the presence of radiation hazard in the vicinity, the trefoil; or the abstract wheelchair design making it known that there is a facility nearby suitable for the use of handicapped persons.

Each mode of communication -- iconic, indexical, symbolic (or emblematic) -- has a set of advantages and a corresponding set of disadvantages, which are both context-bound (see further Sebeok 1976, Ch. 8). Since the context is far from predictable at any stage over the next 10,000 years, and, with the passage of time, is bound to become increasingly equivocal, it will be recommended that all signs be constructed of a mixture of the three modes. While this intermingling will still not be fail-safe, it is certain that the more redundancy is built into the system, the more this will tend to ensure accurate decoding by any destination. The implications of this statement are further developed below. 


\section{SOME PROBLEMS OF IMAGING}

At this point, some comments are in order about certain predictable problems involving iconic, specifically, image-based coding. Two standard books on this subject are by Kennedy (1974) and by Hagen (1980); see also Cabe's compendiary yet comprehensive account (1980), for a recent review of the most critical issues. It should be stressed that there is substantial disagreement on the extent to which pictorial perception depends on specific cultural experience, certainly a major source for human individual differences. Obviously, pictures give some humans some information on some occasions; but the "how" and "when" are complicated questions, and the answers are neither obvious nor should be taken for granted in circumstances as delicate as our project demands.

There are stick-figures, cartoons, sketches, paintings, photographs, and a host of other possibilities for pictorial representation, with varying degrees of accuracy; the perception of all depictions, moreover, varies across species, cultures, and times. For example in the crowd scene in Figure 3, are the people fighting, dancing, or engaged in some other activity?

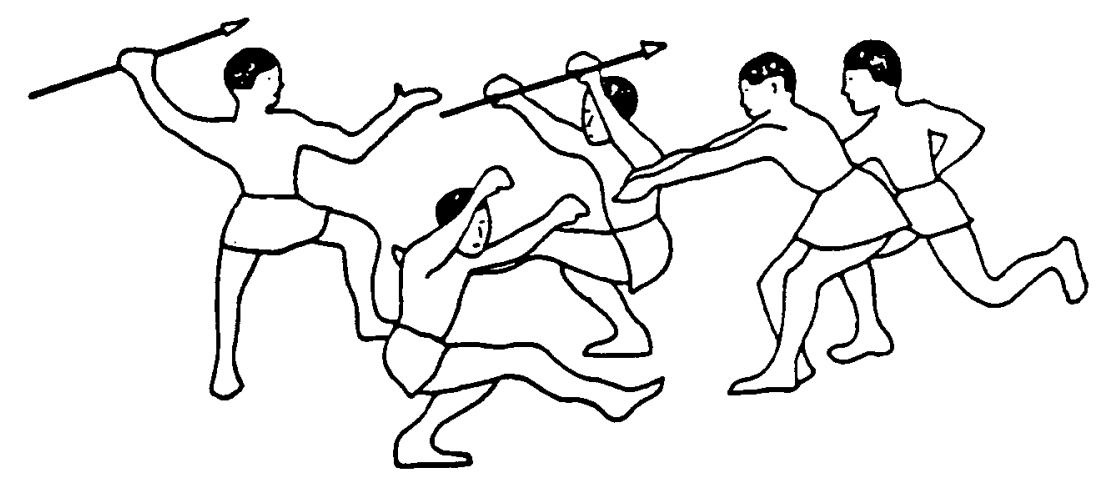

Figure 3. An Ambiguous Image (after Kennedy, 1974, p. 70) (Reprinted by permission of Jossey-Bass Inc.)

What is intimated here is by no means that images should not be used, but rather that they be selected with extreme forethought, and that they always be 
incorporated into a framework that judiciously intermingles icons with symbols, supplementing the pair with indexes whenever that, too, is feasible. The best guess of informed scientists, based on terrestrial cases, is that the "greeting cards" carried on the Pioneer and Voyager probes would more likely than not be devoid of meaning to "extraterrestrial intelligence", because of a lack of common context as well as distinct wiring of perceptual apparatus. Even if "intelligent" life beyond earth were to exist, "the weight of evolution stresses the unlikelihood of the appearance of humanoid forms elsewhere in the Universe" (Feinberg and Shapiro 1980:409-4101) and it is therefore wholly unreasonable to expect that a creature possessing a comparable apparatus for decoding and interpreting information has been produced by independent biological processes on another planet. Even here on earth every species carries a different Umwelt, or "cognitive map", of its environment (Uexku11 1980:291-388), no one of which can be considered "more real" than any other. 


\section{CHANNELS}

Every form of physical energy propagation can be used as a channel for conveying messages. To mention only the most common links used in one corner or another of the animal kingdom, these are: chemical, optical, acoustic, tactile, electric, temperature-based, different combinations of the aforementioned, and others. It is important, furthermore, to appreciate that human senses register only a small portion of ambient stimuli. Acoustically and optically, for example, as already pointed out, we are dependent upon a narrow range of hearing and seeing; i.e., we can register only restricted frequencies. It is very difficult to foretell what sensory prostheses will be at our disposal in future decades and centuries, and one must further allow for the possibility -- indeed, in the opinion of many, likelihood -- that "human interference" will be carried out only indirectly by humans, through the mediation of programmed robots equipped perceptually by unpredictable bionic devices. The problem of choosing what constellation of channels to store the information to be transmitted into the future in, thus assumes considerable importance. Here, once again, redundancy offers the best hope; all channels that seem technically feasibly should be utilized. For instance, if the site can be rendered repulsively malodorous for a lengthy period, that would be, at least provisionally, a deterrent against casual exploration; no one, however, would advocate exclusive reliance upon the olfactory channel as a "final solution". 


\section{WRITTEN RECORDS AND DECIPHERMENT}

Excellent historical surveys of written records and decipherment were published by Ge1b, among other works of his, under the above title (1973), with an extensive bibliography on the subject; and, more recently (Gelb, 1980), with an emphasis on the semiotic aspects, especially within the frame of visual communication. The geographical scope includes the long stretch of land extending from Gibraltar to the Yellow Sea. All types of records, their frequency and variety, epigraphy and paleography, are discussed. In all instances, the time-depth is perhaps a third of the time-span of 10,000 years we are concerned with here. The problems of decipherment discussed by this leading authority seem to have but marginal bearing, for they deal with:

1. Decipherment of unknown writings and languages (e.g., hieroglyphic Egyptian, cuneiform Akkadian, and hieroglyphic Hittite);

2. Decipherment of unknown writings used for known languages (e.g., Phoenician and Ugaritic writings, cuneiform 01d Persian, Cypriote, and 01d [runic] Turkish); and

3. Interpretation of unknown languages written in known writings (e.g., Etruscan).

The general rule that applies is that the degree of difficulty of the recovery of extinct languages is linked directly to the degree of relationship between the language to be recovered and comparable languages (Gelb, 1973:270). Methods of decipherment, and the steps involved in this process are briefly but cogently discussed by Gelb. For a much fuller as well as more general discussion of the methodological problems involved, see the outstanding book by Kahn (1967).

Kahn's consideration of the Rosetta stone (ibid.:905-910) is especially illuminating. Although the stone's importance was instantly recogrized as a possible key to a solution of the mystery of hieroglyphics when it was found in 1799, the important point to keep in mind is that its "mere existence...did not make solution automatic" (ibid.:906), as is popularly believed. JeanFrancois Champollion resolved the riddle only in the Fall of 1822. For this and other more technical reasons, the "lesson" of the Rosetta stone is not relevant to the matters at hand.

Gelb (1980:19-20) lists the various systems and devices available to human beings. His initial division is between (a) Momentary, and (b) Stable. 
The first category is not applicable here. The second category enumerates three sets of subcategories, to wit:

1. "Semasiographic devices or forerunners of writing by means of markings on objects or on any more or less durable material or by means of shapes or color of objects..." Some of these are descriptive-representational devices, which include both pictorial communication and pictorial art, magico-religious representation and narrative representation, as well as seal iconography. For the problem at hand, some sort of narrative representation wi11, undoubtedly, be required, although it will not be sufficient.

2. "Phonographic systems or full writing, by means of markings characterized by close correlation with [some] oral language." This group includes logo-syllabic systems, syllabic systems, and alphabetic systems.

3. "Para-graphic devices or systems, by means of markings occurring within and in addition to writing proper characterized by loose correlation with oral language." Here belong comic strips and cartoons on the one hand, and emblems of the sort advocated by various members of the Task Force.

The important point is that the principle of redundancy advocated here requires that as many stable systems and devices be utilized as imagination suggests and technology permits.

For the record, it should be added that the world's oldest clay tablets date only from 3000 B.C., although it is theorized that people may have begun to record tax recipts, in the form of clay balls, cylinders, and cones -- in a word, tokens -- perhaps as far back as 8500 B.C. According to Denise Schmandt-Besserat, ancient Sumerians kept the tokens which were used to stamp tablets to keep some sort of record, probably each representing a specific amount of a specific commodity, and, by about 3500 B.C., began storing the tokens inside hollow clay balls, indexing the tokens by making an impression of each token on the outside of the ball. Her view is that, by 3100 B.C., it was realized that the actual, material tokens need not be inside the ball, but that the "indexical" impression on the outside of the ball would suffice. Herein may lie writing's true origins (Anonymous, 1981:4). 


\section{RECOMMENDATIONS (AND RELATED CONSIDERATIONS)}

(A) The opening sentence of Harrison's classic survey of Pandora's Box (1900:99), on the changing aspects of this celebrated mythical symbol, begins: "There is a strange fascination about a mythological character that has retained its vitality up to our own day..." This familiar myth -- which occurs in endless verbal and pictorial (Figures 4 and 5) variants since

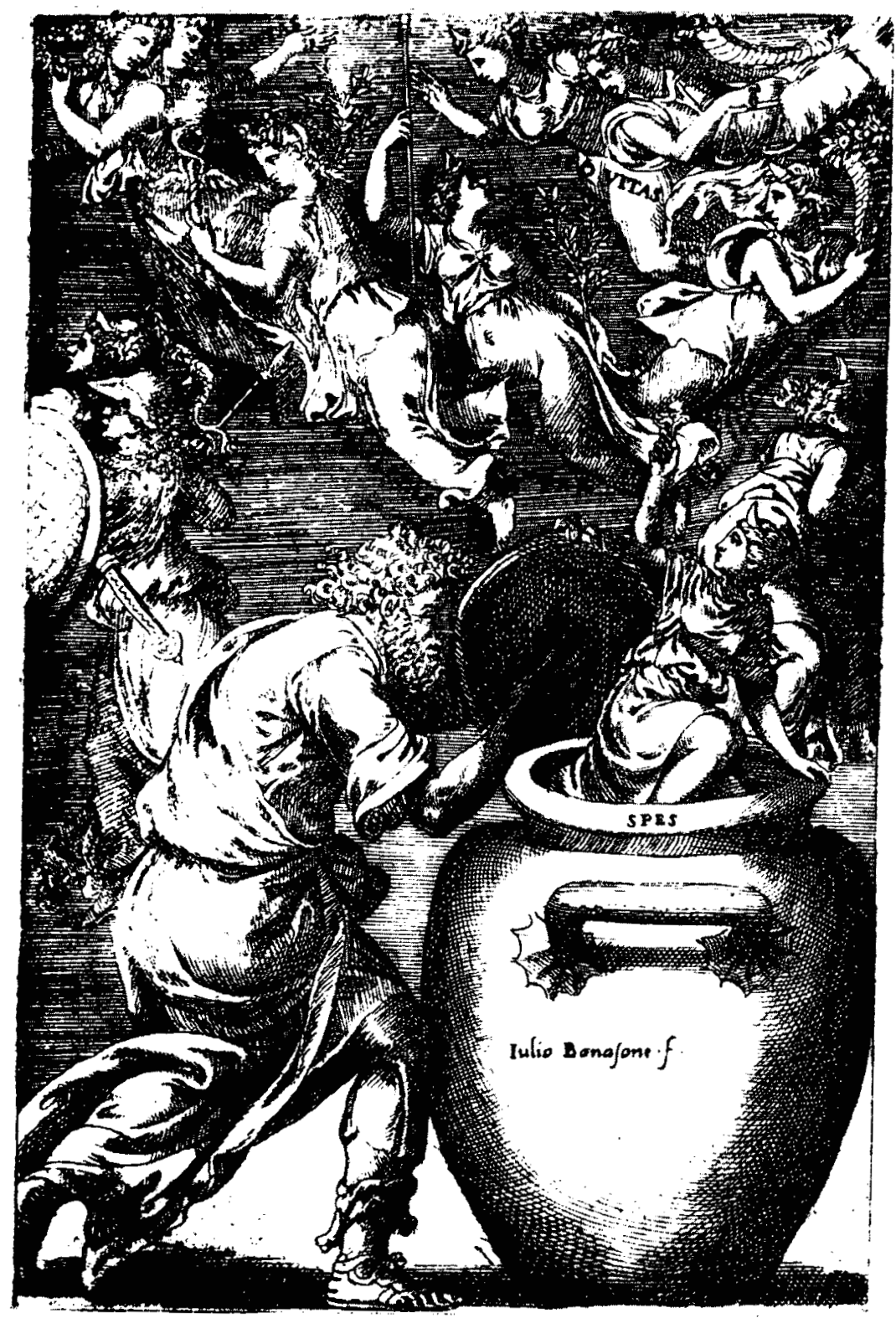

Figure 4. Engraving by Giulio Bonasone, "Man's Opening the Fateful Vessel" (Between 1531-1574) 
Hesiod's famous account of the Pandora story in his Works and Days (Panofsky, 1962) -- deals with the first woman, the beautiful mischief, who opens a forbidden box, out of which comes every evil the flesh is heir to. Pandora and her proverbial box (or jar, ${ }^{3}$ or cask, or vase) appears as an emblem of misery and destruction, as in Figures 4 and 5.

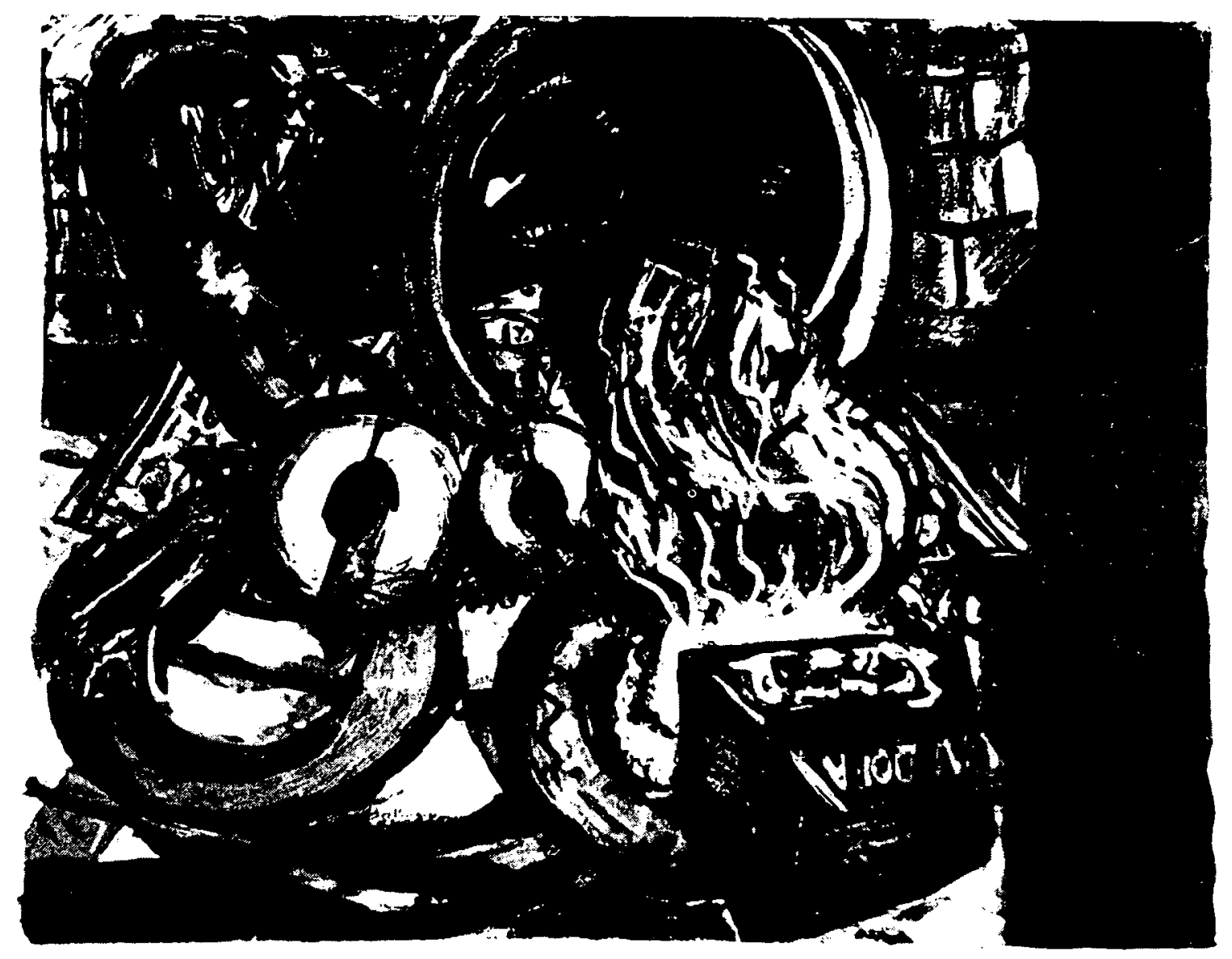

Figure 5. Gouache by Max Beckman, "Pandora's Box" (Begun in 1936, but thoroughly repainted in 1947)

3The original Greek word pithos, commonly mistranslated as "box", referred to a huge earthenware storage jar, "often large enough to serve as a receptacle for the dead...", i.e., that either stands on or is partly buried in the earth (see Harrison, 1900:100, and Panofsky, 1962:7). 
These persistent and widely diffused mythological and iconographic resonances of the assignment to which the Task Force is seeking a resolution lead to the first recommendation, to wit: that information be launched and artificially passed on into the short-term and long-term future with the supplementary aid of folkloristic devices, in particular a combination of an artificially created and nurtured ritual-and-legend. The most positive aspect of such a procedure is that it need not be geographically localized, or tied to any one language-and-culture (although, clearly, when linguistic and ethnic boundaries are crossed, both the verbal component and the associated set of rites are likely to undergo changes and an attenuation of the original rationale).

The legend-and-ritual, as now envisaged, would be tantamount to laying a "false trail", meaning that the uninitiated will be steered away from the hazardous site for reasons other than the scientific knowledge of the possibility of radiation and its implications; essentially, the reason would be accumulated superstition to shun a certain area permanently.

A ritual annually renewed can be foreseen, with the legend retold yearby-year (with, presumably, slight variations). The actual "truth" would be entrusted exclusively to -- what we might call for dramatic emphasis -- an "atomic priesthood", that is, a commission of knowledgeable physicists, experts in radiation sickness, anthropologists, linguists, psychologists, semioticians, and whatever additional expertise may be called for now and in the future. Membership in this "priesthood" would be self-selective over time.

The best mechanism for embarking upon a novel tradition, along the lines suggested, is at present unclear. Folklore specialists consulted have advised that they know of no precedent, nor could they think of a parallel situation, except the we11-known, but ineffectual, curses associated with the burial sites (viz., pyramids) of some Egyptian Pharaohs, e.g., of the 18th dynasty, which did not deter greedy grave-robbers from digging for "hidden treasure".

(B) Although the problems of waste storage are being studied in other countries--among them, Canada, France, Sweden, and West Germany -- and demonstration projects under way abroad are, in some places and some respects, technically further along than those in the U.S., the human intrusion factor is scarcely studied abroad (cf., however, Johansson and Steen, 1981). This 
means that planning should begin immediately to internationalize the kinds of communication measures discussed in this paper, and other Task Force reports. The ultimate design adopted should enjoy the benefit of world-wide thinking about the problems we face and their world-wide implications.

(C) Consideration should be given, at least in passing, to communication in artificial languages, which are mainly of two kinds, general purpose languages, and languages restricted to the communication of some specified subject matter. The use of mathematical formulae is an old and conspicuous special purpose language, and may safely be assumed to embody the physical laws of the universe, understandable throughout the cosmos. Usually, mathematical communication consists of formulae surrounded by bits of vernacular. While the exclusive use of mathematical communication is not recommended, especially not for rite-bound messages, it is reasonable to anticipate a limited use in (a) metamessages and (b) technical messages to be "permanently" stored in archives, libraries, computers, and other long-term repositories. On this subject, see further Freudenthal (1974), and the same author's earlier treatise, Lincos: Design of a Language for Cosmic Intercourse (1960).

(D) One of the pivotal concepts undergirding this whole paper is the notion of *redundancy. In information theory, this term refers to a property of an information source whose *entropy (cf., Rifkin, 1980), $\underline{H}$, is less than the maximum entropy, $\underline{H}_{\max }$, that could be obtained with the same string of messages. Redundancy (or one minus the relative entropy of the source, i.e., the ratio of the actual entropy to $H_{\max }$ ) is an extremely important matter because it reflects the extent to which the efficiency of a communication system can be brought up to the desired standard by improvements in the encoding source (i.e., in our present time).

When the channel is noisy -- as most often it is bound to be -- so that some messages are received erroneously, containing certain distortions, certain extraneous material, the introduction of redundancy will make it much more probable that some or all of the errors may be corrected. Therefore, the purpose of error-correcting codes is to intromit redundancy in a known manner so that corrections can be made at the receiving point -- i.e., by the destination (i.e., in a future era) -- without any further reference to the message source (which, by the nature of the case we are considering, would be impossible). 
(E) Finally, a carefully considered over-all recommendation is urged about the entirety of the communication system under deliberation. This is based on the conviction that a11 human thinking must be in continuity with the past, but also an ineluctable corollary of this proposition, namely, that information tends to decay over time (i.e., the entropy continues to increase, eventually resulting in total incomprehensibility). This is not merely an empirical observation -- witness the evolution of Modern English from AngloSaxon, through Middle English -- but a consequence, more generally, of the Second Law of Thermodynamics. These related concepts are authoritatively discussed, in layman's language, in Wiener (1950); the fact, he says (ibid.:88), that information may be dissipated but not gained is one form of the Second Law of Thermodynamics, which also states that (in an isolated system) the probability that the entropy shall decrease is zero (ibid.:22).

What to do to counter the passage from negentropy to ultimate entropy?

What is being proposed here is a so-called "relay system" of information transmission, which rests on a very simple scheme: to divide the 10,000-year epoch envisaged into manageable segments of shorter, and presumably, reasonably foreseeable periods. Assuming that 10,000 years is equivalent to $\sim 300$ generations of humankind, it is recommended that the messages at the burial site be designed for only three generations ahead, to wit, our children, grandchildren, and great-grandchildren. A clear advantage of any such system would be that the verbal portion could be Modern English, while the averbal portion could easily be extrapolated from existing and universally understood pictorial emblematic strings (e.g., cartoons, stick-figures, or the like).

This message, however, would have to be supplemented by a metamessage -coded in the same combination of familiar verbal/averbal signs -- incorporating a plea and a warning that the object-message at the site be renewed by whatever coding devices seem to be maximally efficient, roughty, 250 years hence. That future object-message should, in turn, incorporate a similar metamessage for the generation 500 years from now to act comparably, and so on, and on, up to 10,000 years ahead.

As for the more permanently stored, elaborated, and scientifically accurate information in archives of the future, a similar set of instructions should make it clear that, as the information begins to decay, it should be updated, and also expanded in the light of improved science, engineering, and technology. 
The disadvantage of the relay system is, of course, that there is no assurance that future generations would obey the injunctions of the past. The "atomic priesthood" would be charged with the added responsibility of seeing to it that our behest, as embodied in the cumulative sequence of metamessages, is to be heeded -- if not for legal reasons, then for moral reasons, with perhaps the veiled threat that to ignore the mandate would be tantamount to inviting some sort of supernatural retribution. 


\section{SUMMARY}

The generalization that a 11 natural languages -- and, by extension, a 11 human communications systems -- change over time is widely accepted. Such semiotic systems, moreover, tend to undergo progressive changes so that their significative functions become unreliable (e.g., Middle English to us), or even totally incomprehensible (e.g., 0ld English to us), when future generations attempt to comprehend them. This is true, in varying degree, of written forms as well as of speech.

It follows that no fail-safe method of communication can be envisaged 10,000 years ahead. To be effective, the intended messages have to be recoded, and recoded again and again, at relatively brief intervals. For this reason, a "relay-system" of communication is strongly recommended, with a built-in enforcement mechanism, for dramatic emphasis here dubbed an "atomic priesthood", i.e., a commission, relatively independent of future political currents, self-selective in membership, using whatever devices for enforcement are at its disposal, including those of a folkloristic character.

In any event, all messages should be as redundant as possible -- a judicious mixture of verbal and averbal components, preferably containing a mixture of iconic, indexical, and symbolic elements.

Finally, the international aspects of the task should be kept in view, so far as feasible, from the outset. 


\section{GLOSSARY OF TECHNICAL TERMS}

AVERBAL: not linguistic.

CHANNEL: a medium wherein a message travels from source to destination. CODE: an agreed transformation, or set of unambiguous rules, whereby messages are converted from one representation to another.

CONTEXT: broadly, the environment of a message; narrowly, all preceding and/or following messages that bear on their significance. CONVENTIONAL MESSAGE: a sign or a string of signs whose power to signify is thought to depend on prior agreement.

DECODING: a transformation, whereby, by operation of code rules, a destination a1ters an incoming message from one representation to another. DESTINATION: where a message ends, i.e., is successively decoded and interpreted.

EMBLEM: a highly formalized symbol, usually in the visual modality. ENCODING: transformation, whereby, by operation of code rules, a source alters a message from one representation to another.

ENTROPY: a term strictiy used in statistical thermodynamics, and loosely used in semiotics to refer to the information rate of a message source. FEEDBACK: kind of feed mechanism that functions to detect an error in a communication system after the error has already occurred.

FEEDFORWARD: source checks to see if message received as expected. FEED PROCESS: see Feed Mechanism.

FEED MECHANISM: a cover term for three types of self-regulated control systems: feedback, feedforward, feedwithin.

FORMULATION: an electro-chemical precoding process assumed to occur in a vertebrate's central nervous system prior to the recoding of a message in an externally communicable representation; generation.

ICON: a sign is said to be iconic when there is a topological similarity between the signifier and its denotata.

INDEX: a sign is said to be indexic in so far as a signifier is contiguous with its signified, or is a sample of it. INTERPRETATION: an electrochemical postcoding process assumed to occur in a vertebrate's central nervous system after the recording of the message as received. 
LANGUAGE: a uniquely human modeling system, such that signifiers (commoniy, sounds or their graphic representation) and signifieds (meanings) are coupled over an infinite domain; verbal communication.

LINGUISTICS: the academic discipline devoted to formal studies of language and of natural languages.

MESSAGE: in communication, a sign or string of signs.

MULTIMESSAGE: a signifier that has a number of distinct meanings, choice of interpretation depending on the time and/or the place.

NATURAL MESSAGE: a sign or a string of signs signifying the same things at a 11 times and in all places.

NOISE: disturbances which do not represent any part of the messages from a specified source; unwanted signs.

PRFGMATICS: that branch of semiotics which studies the uses and the effects of messages; a term parallel to "Syntactics" and "Semantics".

REDUNDANCY: a property assigned to a source by virtue of an excess of rules whereby it becomes increasingly likely that mistakes and reception will be minimized.

SEMIOLOGY: one common synonym for "Semiotics".

SEMIOSIS: the action of a sign, involving three subjects--a sign, its object, and its interpretant.

SEMIOTICS: the doctrine, science, or theory of signs; the subject matter of semiotics is the exchange of any messages whatever and of the system of signs which underlie them.

SIGNIFICATION: the meaning, or sense, of a message.

SOURCE: where a message begins, i.e., is successively formulated and encoded. SYMBOL: a sign without either similarity or contiguity, but only with a conventional link between its signifier and its denotata, and with an intensional class for its designator.

TRANSOUCTION: transformation from one form of energy into another. VERBAL: linguistic. 


\section{REFERENCES}

Anonymous, 1981. "First Impressions", The Sciences, No. 23, p. 4.

Bogart, Dodd H., 1980. "Feedback, Feedforward, and Feedwithin: Strategic Information in Systems", Behavioral Science, No. 25, pp. 237-249.

Bredehoeft, John D., and Tidu Maini, 1981. "Strategy for Radioactive Waste Disposal in Crystalline Rocks", Science, No. 213, pp. 293-296.

Cabe, Patrick A., 1980. "Picture Perception in Non-Human Subjects", The Perception of Pictures, Vol. 2, M. A. Hagen, ed., Academic Press, New York, NY, pp. 305-343.

Cherry, E. Colin, 1978. On Human Communication: A Review, a Survey, and a Criticism, The MIT Press, Cambridge, MA.

Feinberg, Gerald, and Robert Shapiro, 1980. Life Beyond Earth: The Intel1igent Earthling's Guide to Life in the Universe, William Morrow, New York, NY.

Freudentha1, Hans, 1960. Lincos: Design of a Language for Cosmic Intercourse, North-Holland, Amsterdam, Netherlands.

Freudentha1, Hans, 1974. "Cosmic Language", Current Trends in Linguistics, No. 12, pp. 1019-1042, Thomas A. Sebeok, ed., Mouton, The Hague, Netherlands.

Ge1b, Ignace J., 1973. "Written Records and Decipherment", Current Trends in Linguistics, No. 11, pp. 253-284, Thomas A. Sebeok, ed., Mouton, The Hague, Netherlands.

Gelb, Ignace J., 1980. "Principles of Writing Systems Within the Frame of Visual Communication", Processing of Visible Language, Vol. 2, pp. 7-24, Paul A. Kolers, Merald E. Wrolstad, and Herman Bouma, eds., Plenum, New York, NY. 
Hagen, Margaret A., 1980. The Perception of Pictures, Academic Press, New York, NY.

Harrison, Jane E., 1900. "Pandora's Box", The Journal of Hellenic Studies, No. 20, pp. 99-114.

Jacob, François, 1965. Leçon Inaugurale, Collège de France, Paris, France.

Jakobson, Roman, 1965. "Quest for the Essence of Language", Diogenes, No. 51, pp. 21-37.

Jakobson, Roman, 1970. Main Trends in the Science of Language, Harper \& Row, New York, NY.

Johansson, Thomas B., and Peter Steen, 1981. Radioactive Waste from Nuclear Plants, University of California Press, Berkeley, CA.

Kahn, Davis, 1967. The Codebreakers: The Story of Secret Writing, MacMillan, New York, NY.

Kennedy, John M., 1974. A Psychology of Picture Perception, Jossey-Bass Inc., San Francisco, CA.

Loftus, Elizabeth F., 1980. Eye Witness Testimony, Harvard University Press, Cambridge, MA.

Miller, Eugene S., 1979. "Hume's Reduction of Cause to Sign", The New Scholasticism, No. 43, pp. 42-75.

Morris, Charles, 1971. Writings on the General Theory of Signs, Mouton, The Hague, Netherlands.

Morris, Desmond, 1977. Manwatching: A Field Guide to Human Behavior, Harry M. Abrams, New York, NY. 


\section{DISTRIBUTION LIST}

ACRES AMERICAN INC

A. S. BURGESS

ROBERT H. CURTIS

R. STRUBLE

AEROSPACE CORP

BARRETT R. FRITZ

AGBABIAN ASSOCIATES

CHRISTOPHER M. ST JOHN

ALABAMA DEPT OF ENERGY

CAMERON MCDONALD

ALABAMA STATE GEOLOGICAL SURVEY

THORNTON L. NEATHERY

AMARILLO PUBLIC LIBRARY

AMERICAN EMBASSY - SWEDEN

AMERICAN NUCLEAR INSURERS DOTTIE SHERMAN

ANALYSIS AND TECHNOLOGY INC T. MAZOUR

APPLIED MECHANICS INC GRAHAM G. MUSTOE

ARGONNE NATIONAL LABORATORY

DAVID F. FENSTER

WYMAN HARRISON

J. HOWARD KITTEL

MARTIN SEITZ

MARTIN I. STEINDLER

ARINC RESEARCH CORP H. P. HIMPLER

ARIZONA PUBLIC SERVICE COMPANY HENRY W. RILEY. JR.

ARTHUR D. LITTLE INC

AVIVA BRECHER

CHARLES R. HADLOCK

ATKINS RESEARCH \& DEVELOPMENT - UNITED KINGDOM

T. W. BROYD

ATOMIC ENERGY CONSULTANTS

DONALD G. ANDERSON

ATOMIC ENERGY CONTROL BOARD -

CANADA

KEN SHLILTZ

ATOMIC ENERGY OF CANADA LTD

T. CHAN

ANN QUINN

F. P. SARGENT

ATOMIC ENERGY RESEARCH ESTABLISHMENT

- UNITED KINGDOM

D. P. HODGKINSON

ATOMIC INDUSTRIAL FORUM INC

EMANUEL GORDON

AUSTRALIAN ATOMIC ENERGY COMMISSION

BABCOCK \& WILCOX

INFORMATION SERVICES

BATIELLE COLUMBUS DIVISION

SANFORD G. BLOOM

IOHN T. MCGINNIS

JEFFREY L. MEANS

NEIL E. MILIER

STEPHEN NICOLOSI

KENNETH R. YATES

BATTELLE MEMORIAL INSTITUTE JAMES DUGUID

BATTELLE NORTHWEST LABORATORIES RICHARD STRICKERT

BE INC

K. I. ANDERSON

BECHTEL GROUP INC

TOM S. BAER

DON B CRANDALL

LESLIE I. JARDINE

R. C. LOVINGTON
N A NORATAN

CERALD L. PALAL

U. YOLING PARK

RICHARD J. TOSETTI

BELGISCHE GEOLOGISCHE DIENST - BELGIUM NOEL VANDENBERGHE

BENDIX FIELD ENGINEERING CORP

BILL GRAHAM

DONALD LIVINGSTON

MICHAEL H. MOBIEY

JOHN C. PACER

BERKELEY GEOSCIENCES/HYDROTECHNIQUE

ASSOCIATES

BRIAN KANEHIRO

BHABHA AIOMIC RESEARCH CENIER - INDIA V.SUKL:NORAN

BLACK \& VEATCH

M. JOHN ROBINSON

BOEING ENGINEERING AND CONSTRUCTION COMPANY

R. B. CAIRNS

BRENK SYSTEMPLANUNG - W. GERMANY H. D. BRI:NK

BRIGHAM YOUNG UNIVERSITY

HAROLD B. LEI LIBRARY

WIIIAN M TINMINS

BROOKHAVEN NATIONAL LABORATORY

M. S. DAITS

P. W. LEV

CLAL:DIO PFSCATORI

PETER SOO

HEIEN TODOSOW (2)

BUNDESANSTALI FUR GEOWISSENSCHAFTEN

UND ROHSTOFFE - W. GERMANY

MICHAEL LANCIER

HELMI'T VINZLAFF

BUNDESMINISIERIUM FUR FORSCHUNG UND

TECHNOLOGIE - W. GERMAN ROLF-PETER RANDL

BUREAU DE RECHERCHES GEOLOC'RUES ET

MINIERES - FRANCE

PIIRREF. PIAL:DECERF

BURNS AND ROE INDUSTRIAL SERVICES CORP JOHN PIRRO

C.F.H.F.

BILL DL:FING

CALIFORNIA ASSEMBLY COMMITTEE ON

NATURAL RESOURCES

GENE VARANINI

CALIFORNIA DEPT OF CONSERVATION PERRY ANIINHTO

CALIFORNIA DIVISION OF MINES \& GEOLOGY ROBERT H. SYDNOR

CAPITAL AREA GROUND WATER

CONSERVATION COMMISSION A. $\therefore$ TLRCAN.IR

CARNEGIE-MELLON UNIVERSITY INDIRA NAIR

CAYUGA LAKE CONSERVATION ASSOCIATION INC D. S. KIILH

CENTER FOR ENVIRONMENTAL

INFORMAIION INC FREDERICK W. STOSS

CENTER FOR INTERDISCIPLINARY STUDIES DAVID M. ARMISTRONC;

CENTRE D INFORMATIQUE GEOLOGIQUE FRANCE

(iHISL AIN DIMARSII
CHALMERS UNIVERSIIY OF TECHNOLOGY SWEDEN

BERT ALIARI)

CITIZENS INSTITUTE FOR A POSITIVE ENERGY POLICY

LINDSAY ALIDIN

CITY OF MONTICELLO

RICHARD TERRY

CLARK UNIVERSITY

IEANNF $X$ KASPERSON

CLEVELAND ELECTRIC ILLUMINATING COMPANY

PALIL G. KLANN

COLORADO OUTWARD BOUND SCHOOI

DAVID L. BUIRGILR

PETER ANTHONY ONEII

COLORADO SCHOOL OF MINES W. HUSTRLIIID)

COLUMBIA UNIVERSITY A1. ASHIRAF NIAIIAH

CONGRESSIONAL INFORMATION SERVICE INIMIYC MCORIW

CONNECTICUT DEPT OF ENVIRONMENTAL PROTECIION KHIIN MCCARIHY

CONNECTICUT STATE DEPARTMENT OF

HEAL TH SERVICES

MARGERYA COHIFN

CONROY ENGINEERINC PIIER CONROY

CONTINENTAL GROUP INC CHORCIE I ROLLIND

CORNEUL UNIVERSITY IRED H. KLIL.HAWY

CORTLAND COUNTY HEALTH DEPT J. V.fllis.

D.R.E. KARI. J. ANANIA

DAMES \& MOORE

RON KIAR IIFFREYKIAION

DAPPOLONIA CONSULTING ENGINEERS INC ISAK. DONOHIIE ABBY RORRISI

AMINAHAMI)Y

CARL S SCHLIBLRI

DAWCON MANAGEMENT CONSULING SERVICE

DAVIOA WIBSIER

DEAF SMITH COUNTY LIBRARY

DELAWARE CUSTOM MATERIEL INC HOWARD NOVIICH

DEPI OF ENERGY, MINES AND RESOURCES CANADA

A. S. IUDGE

DUGOUT RANCH ROBERI \& HEIDI RIDDD

DYNATECH R/D COMPANY SIEPHENE. SMIIH

F.I. DU PONT DE NEMOURS \& CO D. H. TLRNO

E.L.H. PUBLICATIONS - THE RADIOACTIVE EXCHANCE

HEIMINSKI \& WILKLN

E.R. JOHNSON ASSOCIATES INC

E. R. JOHNSON

G. I. IOHNSON

EAL CORP ILON IFVINTHAL

EARTH SCIENCE AND ENGINEERING INC LOL: BLANCK 
EAST COMPANY INC RAYMOND PEREZ

EAST TENNESSEE STATE UNIVERSITY ALBERT F. IGLAR VAY A. RODMAN

EBASCO SERVICES INC ZUBAIR SALEEM RAYMOND H. SHUM

ECOLOGY CENTER OF LOUISIANA ROSS VINCENT

EDISON ELECIRIC INSTIIUTE R. E. L. STANFORD

EDS NUCLEAR INC

C. SUNDARARAIAN

EG \& G IDAHO INC LOW-LEVEL RADIOACTIVE WASTE ROGER A. MAYES ROBERT M. NEILSON. IR

ELECTRIC POWER RESEARCH INSTITUTE CHAIM BRALN

ELEKTRIZITAETS-GES. LAUFENBURG -

SWITZERLAND H. N. PATAK

ELSAM - DENMARK A. V. JOSHI ARNE PEDERSEN

ENERGY FUELS NUCLEAR GEORGE A. JONES

ENERGY FUELS NUCLEAR INC DON M. PILLMORF

ENERGY RESEARCH GROUP INC MARC GOLDSMITH

ENGINEERS INTERNATIONAL INC FRA.\CIS S. KE.NDORSKI

ENVIRONMENT CANADA CLALDE BARRALD

ENVIRONMENTAL POLICY INSTITUTE DHWD W. BERICK FRED \IILL AR

ENVIROSPHERE COMPANY ROGER C. ADOERSON K. E. LIVD-HOWE

EXXON NUCLEAR COMPANYINC GER ALD L. RITTER

EXXON NUCLEAR IDAHO COMPANY INC VATHAY A. CHIPMAAI ROCER \HE\R CARI II AYITIRE

FENIX \& SCISSON INC JOSE \& VIACHADO CHARLE\EL LPARKMIA

ILORIDA DEPT OF ENVIRONMENTAL RECULATION H.AVILTOV OVE.

FLORIDA INSTITUTE OF TECHNOLOCY JOSEPH A. A.NGELO. JR.

FLORIDA POWER \& IIGHT COMPANY IA YES R. TOMONTO

'LORIDA STATE UNIVERSITY IOSEPH F. DONOGHLE

FONTANA CORROSION CENTER DIGBY MACDONALD

FORD, BACON \& DAVIS INC ROBERT D. BAIRD DARRELL H. CARO ROBERTF. OVERMYER BLRTON I THAMER

FOSTER-MILLER ASSOCIATES INC NORBERT PAAS

FOUR CORNERS COMMUNITY MENTAL HEALTH CENIER BOB GREENBERC
FOX CONSULTANTS INC MIKE E. BRAZIE

FRIENDS OF THE EARTH LOUIS BUCKLIN RENEE PARSONS

GABIE BETTS BURTON MEMORIAL LIBRARY

GARTNER LEE ASSOCIATES LTD - CANADA ROBERT E. I. LEECH

GENERAL ATOMIC COMPANY

MICHAEL STAMATELATOS

GENERAL COURT OF MASSACHUSETTS TIMOTHY I. BURKE

GEOLOGICAL SURVEY OF CANADA IEFFREY HUME JOHN SCOTT

GEOLOGICAL SURVEY OF DENMARK L.I. ANDERSEN

GEORESULTS INC DAVID SNOW

GEORGIA INSTITUTE OF TECHNOLOG MELVIN W. CARTER

GEOFFREY G. EICHHOLZ

ALFRED SCHNEIDER

CHARLES E. WEAVER

GEOTECHNICAL ENGINEERS INC RONALD C. HIRSCHFELD

GEOTHERMAL ENERGY INSTITUTE DONALD F. X. FINN

GEOTRANS IAMES MERCER

GESELLSCHAFT F. STRAHLEN U. UMWEL TFORSCHUNG M.B.H. - W. GERMANY

WOLFGANG BODE

H. . IOOSER

FRANZ PERZL

GILBERT/COMMONWEALTH JERRY L. ELLIS

COLDER ASSOCIATES

DONALD M. CALDMELL

MELISSA MATSON IV VOSS

GOLDER ASSOCIATES - CANADA CLEMENTM.K. YLEN

GRAND COUNTY PUBLIC UBRARY

GSE NUCLEAR MOHSEN NIROOMAND-RAD

GIC GEOLOGIC IESTING CONSULTANTS LTD CANADA

JOH: F. PICKENS

GULF INTERSTATE INC THOMAS J. HILL

GULF STATES UTILITIES COMPANY F. INIV DRAPER

H \& R TECHNICAL ASSOCIATES INC WILIIAM R RHYUE

HAHN-MEITNER-INSTITUT FUR KERNFORSCHUNG BERLIN KLALS ECKART MAASS

HANFORD ENGINEERING DEVELOPMENT LABORATORY

ROBERT FINZIGER W. E. ROAKE

HARVARD UNIVERSITY CHARLES W BLRNHAM DADE W: MOELLER

HATTIESBURG PUBLIC LIBRARY

HIGH COUNTRY CITIZENS ALLIANCE DON BACHMAN

HIGH PLAINS UNDERGROUND WAIER DISTRICT

TROY SLBBLETT
HIGH PLAINS WATER DISTRICT

DON MCREYNOLDS

DON D. SMITH

HITACHI WORKS, HITACHI LID MAKOTO KIKUCHI

HOUGH-NORWOOD HEALTH CARE CENTER GEORGE H. BROWN, MD.

ILLINOIS DEPI OF NUCLEAR SAFETY TERRY R. LASH MILTON ZUKOR

ILIINOIS STATE GEOLOCICAL SURVEY ROBERT E. BERGSTROM KEROS CARTWRIGHI

IMPERIAL COLLEGE OF SCIENCE AND

TECHNOLOGY - ENGLAND B. K. ATKINSON

INDIANA STATE BOARD OF HEALTH HAL S. STOCKS

INSTITUT FUR TIEFLACERUNG - W. GERMANY WERNT BREWITZ H. GIES

KLAUS KUHN E.R. SOLTER

INSTITUTE FOR CHEMICAL TECHNOLOGY - W. GERMANY REINHARD ODOI

INTER/FACE ASSOCIATES INC RON GINGERICH

INTERA ENVIRONMENTAL CONSULTANTS INC F. J. PEARSON IR. LARRY RICKERTSEN ROBERT WILEMS

INTERNATIONAL ATOMIC ENERGY AGENCY AUSTRIA FRANK A. OHARA

INTERNATIONAL ENERGY ASSOCIATES LTD BLYTHE K. LYONS

INTERNATIONAL ENERGY SYSTEMS CORP JOHA A. BOWIIIS

INIERNATIONAL ENGINEERING COMPANY INC

TERRY L STEINBORN

MAX ZASLAWSKY

INIERNATIONAL RESEARCH AND

EVALUATION R. DANFORD

IOWA STATE UNIVERSITY MARTIN C. EDELSON BERNARD I SPINRAD

IRT CORP I. STOKES

ISMES - ITALY F. CERA

IACKSON METROPOUITAN LIBRARY

JACKSON STATE UNIVERSITY ESTLSS SMITH

JACKSON-GEORGE REGIONAL LIBRARY

IAY L. SMITH COMPANY INC IAY L. SMITH

IGC CORPORATION - IAPAN MASAHIKO MAKINO

IOHNS HOPKINS UNIVERSITY IAREDL COHON

JOINT STUDY COMMITIEE ON ENERGY I W EDWARDS IR.

KAISER FNGINEERS INC W. J. DODSON H. L. JULIEN

KalAMAZOO COLLEGE RALPH M DIAL

KANSAS DEPT OF HEALTH AND ENVIRONMENT GERALD W. ALLEN 
5

KANSAS STATE GEOLOGICAL SURVEY WILLIAM W. HAMBLETON

KARNBRANSLESAKERHET - SWEDEN LARS B. NILSSON

KELLER WREATH ASSOCIATES FRANK WREATH

KERNFORSCHUNGSZENTRUM KARLSRUHE GMBH - W. GERMANY

K. D. CLOSS

R. KOESTER

KIHN ASSOCIATES HARRY KIHN

KLM ENGINEERING INC B. GEORGE KNIAZEWYCZ

KOREA INSTITUTE OF ENERGY AND RESOURCES (KIER)

CHOO SEUNG HWAN CHONG SU KIM

KQIL

KUTA RADIO

KYOTO UNIVERSITY - JAPAN

YORITERU INOUE

LACHEL HANSEN \& ASSOCIA IES INC DOUGLASE. HANSEN

LAKE SUPERIOR REGION RADIOACTIVE WASTE PROJECT C. DIXON

LAW ENGINEERING TESTING COMPANY JAME5 L. GRANT

LAWRENCE BERKELEY LABORATORY

JOHN A. APPS

EUGENE BINNALL.

THOMAS DOE

NORMANM. EDELSTEIN

JANE LONG

I. WANG

LAWRENCE LIVERMORE NATIONAL

LABORATORY

DAEH. CHUNG

EDNAM. DIDWELL

FRANCOISE. HEUZE

THOMASE. MCKONE

LAWRENCE D. RAMSPOTT (2)

W G SUTCLIFFE

TECHNICAL INFORMAIION DEPARTMENT

$-53$

JESSE L. YOW. JR.

LEAGUE OF WOMEN VOTERS OF UTAH PAULA MADSEN

IOCKHEFD ENGINEFRING \& MANAGEMENT COMPANY

STEVE NACHT

LOS ALAMOS NATIONAL LABORATORY

P. L. BUSSOLINI

WAYNE R. HANSEN

CLAUDE HERRICK

W. C. MYERS

DONALD T. OAKLEY

K. K. S. PILLAY

LOS ALAMOS TECHNICAL ASSOCIATES INC R. J. KINGSBURY

LOUISIANA DEPT OF TRANSPORTATION \&

DEVELOPMENT

GEORGE H. CRAMER, II

LOUISIANA GEOLOGICAL SURVEY

PEGGY ROONEY AUTIN

RENWICK DEVILLE

CHARLES G. GROAT

SYED HAQUE

LOUISIANA NUCLEAR ENERGY DIVISION L. HALL BOHLINGER (3)

LOUISIANA STATE UNIVERSITY

IIMMIE H. HOOVER
LOUISIANA TECH UNIVERSITY LIBRARY

IOUISIANA TECHNICAL UNIVERSITY R. H. THOMPSON

LUBBOCK COUNTY SOIL AND WATER CONSERVATION DISTRICT DON LANGSTON

MAINE BUREAU OF HEALTH DONALD C. HOXIE

MARTIN MARIETTA AEROSPACE - DENVER DIVISION

RICHARD BISSEGGER

MARYLAND DEPT OF HEALTH \& MENTAI

HYGIENE

MAX EISENBERG

MASSACHUSETTS DEPT OF ENVIRONMENTAL QUALITY ENGINEERINC IOSEPH A. SINNOTT

MASSACHUSETTS HOUSE OF REPRESENTATIVES W'ILLIAMI ROBINSON

MASSACHUSETTS INSTITUTE O

TECHNOLOGY

IOHIN DEL:TCH TED CREINHOOD

RICHARD K. I ESTER MARSHA LEVINE

MATERIALS RESEARCH LABORATORY LTD -

CANADA

$$
\text { 5. SINGH }
$$

MCDERMOTT INTERNATIONAL

KAREN L. FLIRLOW

MCMASTER UNIVERSITY - CANADA

L. W SHENIII.

MEMBERS OF THE GENERAL PUBLIC

L. ROBERT ANDERSON

KLIRT BALLING

BREI BLOSSER

IHONAS G. BRADPORD

ROGER H. BROOKS

BRUCF A. BYERS

HAZEI (HAPAIAN PHD)

LAWRENCE (HAST, PH.D)

TOM \& SLSAN (LAWSON

STEVI CONEWAY

M. VAL DALION

KENNETHE ALICT M. DROGIN

ROBERI DL DER

JEAN EARDIFY

THALINASP. FHR

ART FORAN

BOB GAMAMEIN

CARL A GIESE

SHIRLFY. GIIFORI)

MICHAFI. I GIIBFR

STEVE \& SLI CIIISDORI

OSW ALD H GRIACER

DOL:GLAS H. GREINIF!

KENNFTH GLSCOH

WILLIAMR. HAASH.

ROBERT HIGGINS

DAVID W IOHINSON

KENNETHS. JOHASON

CRAIC W: JONES

JOSEPH KEYSER

IHOMASH. LANGIVIN

MAX NCDOWELL

IEFF MEADOWS

A. ALAN MOGHISSI

BARBARA MORRA

THEA NORDIING

CAROLINE PFTTI
MARIIN RATHKH

RIP. ( . HARDY RIDI)

IONI \& MIARY RIIS

OANII SALOII

OMINSHIRANCI

NORNIAN C SMIIH

PAIRICIASNYDIR

P. I STRAIIY-CiRHG

AMRCI'FRII SWIENG

IOFI. SHISHFR

M. I. SZI.IINSKI

MARK (II)ALL

CARY W ACINLK

MARIIN \& ILAINI WALIIR

INAMII WHII

LINDA WIIIKOP

SLSAN WOOIII

SIPHIN G. ILMBA

MICHAEL BAKER, IR. INC

(.). IOLIHIII

MICHIGAN DEPT OF NATURAL RESOURCES

R. IHOMAS SI GAII

MICHIGAN DEPT OF PUBLIC HEALTH

CIIORCiI $U$ BRI CIINIANN

III I. IACILR

MICHIGAN ENVIRONMFNTAI COUNCII ROOM 305

MICHIGAN ENVIRONMENTAL PROTECTION

COMMITTEE

DAVI CHAPMAN

MICHIGAN GEOLOGICAL SURVEY ROBERT C. REI D

MICHIGAN PUBLIC SERVICE COMMISSION RON CAIIIIN

MICHIGAN STATE UNIVERSITY WIILIAM C. TAYIOR

MINNESOTA FNVIRONMENTAL QUALITY

BOARD

RICHARDPAION

MINNESOTA GEOLOGICAL SURVEY I.INIOA I. IIHMAN MAIIS. WALION

MINNESOTA STATE ENERGY AGENCY

MINNESOTA STATE SENATE CONRADVICIA

MISSISSIPPI ATIOR NEY GENERAIS OFFICE MACK CAMIRON

MISSISSIPPI BUREAU OF GFOIOGY MICHAII B. H. BOC.RAI)

MISSISSIPPI CITIZENS AGAINST NUCLEAR DISPOSAL

STANIIY DIAAN HIINI

MISSISSIPPI DEPT OF ENERGY AND

IRANSPORTATION

RONAIDIIORSYIH"

MISSISSIPPI DEPT OF NATURAL RESOURCES ALVIN R. BICKFR, IR

CHARLISI BIALOCK (URTIS W SIOVIR

MISSISSIPPI EMERGENCY MANAGEMENT AGENCY

IAMFS E. MAHFR

MISSISSIPPI LIBRARY COMMISSION

SARA TUBH

MISSISSIPPI MINERAL RESOURCES INSTITUTE

MISSISSIPPI STATE BOARD OF HEALTH EDDIE S. FILNT GUYR. WILSON

MISSISSIPPI STATE HOUSE OF REPRESENTATIVES

HIILLMAN IIROME FRALILR 
MISSISSIPPI STATE UNIVERSITY

TROY J. LASWELL

VICTOR L. ZITTA

MITRE CORP

LESTER A. ETTLINGER

MITSUBISHI METAL CORP TATSUO ARIMA

MOAB NUCLEAR WASTE INFORMATION OFFICE

MICHAELENE PENDLETON (2)

MONTANA BUREAU OF MINES AND

GEOLOGY

EDWARD C. BINGLER

MONTICELLO HIGH SCHOOL LIBRARY MEDIA CENTER

MONTICELLO NUCLEAR WASTE

INFORMATION OFFICE

CARL FISEMANN (2)

NAGRA - SWITZERLAND HANS ISSLER

NATIONAL ACADEMY OF SCIENCES IOHN T. HOLLOWAY HAROLD L. JAMES

NATIONAL AERONAUTICS AND SPACE ADMINISTRATION

MICHAEL R. HELFERT MICHAEL ZOLENSKY

NATIONAL HYDROLOGY RESEARCH

INSTITUIE - CANADA

DENNIS I. BOTTOMLEY

NATIONAL PARK SERVICE

DONALD F. GILLESPIE

CECIL D. LEWIS. JR.

NATIONAL PARKS \& CONSERVATION

ASSOCIATION

T. DESTRY IARVIS

TERRI MARTIN

NATIONAL SCIENCE FOUNDATION ROYAL E ROSTENBACH

NAVAL WEAPONS STATION EARLE GENNARO MELLIS

NEW ENGLAND NUCLEAR CORP KERRY BENDERT CH.ARLES B. KILLIA.)

NEW JERSEY INSTITUTE OF TECHNOLOGY BE. STEVENSON

NEW MEXICO BUREAU OF MINES AND MINERAL RESOURCES FRANK E. KOTTLOWSKI

NEW MEXICO ENVIRONMENTAL EVALUATION GROUP ROBERT H. NEILL

NEW YORK DEPI OF HEALTH DALID AXELROD. M.D.

NEW YORK ENERGY RESEARCH \&

DEVELOPMENT AUTHORITY JOH\P. SPATH 181

NEW YORK GEOLOGICAL SURVEY ROBERT H. FAKLNDINYY

NEW YORK LEGISLATIVE COMMISSION ON SCIENCE \& TECHNOLOGY IAMES T. MCFARLAND

NEW YORK STATE ASSEMBLY ANCELO ORAZIO

NEW YORK STATE ATTORNEY GENERALS OFFICE EZRA I. BIALIK

NEW YORK STATE ENERCY RESEARCH AND DEVELOPMENT AUTHORITY JOHN C. DEMPSEY

NEW YORK SIAIE GEOLOGICAL SURVEY JAMES R. ALBANESE
NEW YORK STATE HEALTH DEPT JOHN MATUSZEK

NEW YORK STATE PUBLIC SERVICE COMMISSION FRED HAAG

NEW YORK STATE SENATE RESEARCH SERVICE DAVID WHITEHEAD

NORTH CAROLINA STATE SENATE I. R. ALSBROOK

NORTH DAKOTA GEOLOGICAL SURVEY DON L. HALVORSON

NORTH DAKOTA SIATE UNIVERSITY JOHN M. HALSTEAD

NORTHEAST OHIO FOUR COUNTY REGIONAL PLANNING \& DEVELOPMENT ORGANIZATION JOHN C. PIERSON

NOR THEAST UTILITIES SERVICE COMPANY PATRICIA ANN OCONNELL

NORTHWESTERN UNIVERSITY BERNARD J. WOOD

NTR GOVERNMENT SERVICES THOMAS $V$. REYNOLDS

NUCLEAR ASSURANCE CORP JOHN V. HOUSTON JEAN RION

NUCIEAR ENERGY AGENCY/OECD - FRANCE ANTHONY MULLER

NUCLEAR SAFETY RESEARCH ASSOCIATION IZUMI KURIHARA

NUCLEAR WASTE WATCHERS HELEN LETARTE

NUS CORP

U. G. BELTER

RODNEY J. DAVIS

i. BARRIE MCLEOD

DOLGLAS D. ORVIS

YONGM.PARK

DOLGLAS W: TONKAY

NUS CORPORATION

DR BARRY N.NAFT

NUTECH ENGINEERS INC

GARRISON KOST

PALL C. SLN

NWT CORP

W. L. PEARL

OAK RIDGE NATIONAL LABORATORY

I. O. BLOMEKE

H. C. CLAIBORNE

ALLEN G. CROFF

LFSLIE R. DOLE

CATHY S. FORE

DAVID C. KOCHER

E. M. OBLON

E. B. PEFLLE

ELLEND. SMITH

STEPHENS STOW

OHIO DEPT OF HEALTH

ROBERT M. QLIILLIN

OKLAHOMA STATE DEPT OF HEALTH R. L. CRAIC

ONTARIO HYDRO - CANADA

R. W. BARNES

1. A. CHADHA

K. A. CORNELL

C. I. LEE

ONIARIO MINISTRY OF THE ENVIRONMENT -

CANADA

IAAK VIIRLAND

ORANGE COUNTY COMMUNITY COLLEGE

IAWRENCE E. OBRIEN

OREGON STATE UNIVERSITY

IOHAN C. RINGLL
ORGANISATION FOR ECONOMIC COOPERATION AND DEVELOPMENT FRANCE

PETER D. JOHNSTON

OTHA INC

JOSEPH A. LIEBERMAN

P.O.W.E.R

TIM REVELL

P.O.W.E.R.

RALPH DILLER

PACIFIC NORIHWEST LABORATORY

DON I. BRADLEY

JOHN B. BROWN

H. C. BURKHOLDER

JOHN B. BURNHAM

T.D. CHIKALLA

HARVEY DOVE

FLOYD N. HODGES

J. H. JARRETT

MAXR. KREITER

ROBERT MCCALLUM

J. F. MENDEL

J. M. RUSIN

R. JEFF SERNE

CARL UNRLHH

R. E. WESTERMAN

PARSONS BRINCKERHOFF QUADE \&

DOUGLAS INC

T. R. KUESEL

ROBERT PRIETO

MARK E. STEINER

PARSONS-REDPATH

GLEN A. STAFFORD

PENNSYLVANIA HOUSE OF REPRESENTATIVES JAMES MANDERINO

PENNSYIVANIA STATE UNIVERSITY MICHAEI. GRUTZECK WILLIAM B. WHITE

PERRY COUNIY CITIZENS AGAINST NUCLEAR WASTE DISPOSAL

MRS. DURLEY HANSON

WARREN STRICKLAND

PETTIS WALLEY

PERRY COUNTY SCHOOLS MANIEL A. COCHRAN

PHYSIKALISCH-TECHNISCHE BUNDESANSTALT -W. GERMANY PETER BRENNECKE HORST SCHNEIDER

PIRGIM

RICHARD LEVICK

POINT BEACH NUCLEAR PLANT IAMES I. ZACH

PORTLAND GENERAL ELECTRIC I. W. I.ENTSCH

PRESQUE ISLE COUR IHOUSE

PSE \& G

IOHN I. MOLNER

PUBLIC LAW UTILITIES GROUP DORIS FALKENHEINER

PUBLIC SERVICE INDIANA ROBERT S. WEGENG

PURDUE UNIVERSITY PAUL S. LYKOUDIS

R.J. SHLEMON AND ASSOCIATES INC R. J. SHLEMON

RALPH M. PARSONS COMPANY JERROLD A. HAGEL

RE/SPEC INC GARY D. CALLAHAN WILIIAM C. MCCLAIN

RED ROCK 4-WHEELERS GEORGE SCHUITY 


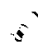

RENSSELAER POLYTECHNIC INSTITUTE JAMES WU

RESOURCE SYSTEMS INSTITUTE

KIRK R. SMITH

RHODE ISLAND GOVERNORS ENERGY OFFICE BRUCE VILD

RHODE ISLAND GOVERNORS OFFICE JOHN A. IVEY

RIO ALGOM CORP DUANE MATLOCK

ROCKWELL HANFORD OPERATIONS

RONALD C. ARNETT

IAMES L. ASH

HARRY BABAD

L. R. FITCH

KARL M. LA RUE

MICHAEL I. SMITH

DAVID L. SOUTH

RICHARD T. WILDE

ROCKWELL INTERNATIONAL ENERGY SYSIEMS CROUP

LAWRENCE I. SMITH

ROGERS \& ASSOCIATES ENGINEERING CORP ARTHUR SUTHERLAND

ROGERS, GOLDEN \& HALPERN JACK A. HALPERN

ROY F. WESTON INC MARTIN HANSON DAVIDHART

RONALD MACDONALD

MICHAEL V. MELLINGER

SAM PANNO

ROBERT SCHULER

HARRY W. SMEDES

LAWRENCE A. WHITE

ROYAL INSTITUTE OF TECHNOLOGY -

SWEDEN

ROGER THUNVIK

RPC INC

IAMES VANCE

S.E. LOGAN \& ASSOCIATES INC

STANLEY E. LOGAN

S.M. STOLLER CORP

ROBERT W. KUPP

SALT LAKE CITY TRIBUNE JIM WOOLF

SAN DIEGO GAS \& ELECTRIC COMPANY LOUIS BERNATH

SAN JOSE STATE UNIVERSITY SCHOOL OF ENGINEERING

R. N. ANDERSON

SAN JUAN COUNTY SHERIFF

S. RIGBY WRIGHT

SAN IUAN RECORD

DEBORAH A. MARCUS

IOYCE MARTIN

SANDIA NATIONAL LABORATORIES

I.IBRARY

KEN BEALL

SHARI.A BERTRAM

MARGARET S. CHU

NANCY C. FINLEY

I. KEITH JOHNSTONE.

A. R. LAPPIN

R. W. LYNCH

MARTIN A. MOLECKE

IAMES T. NEAL

NESTOR R. ORTIZ

SCOTI SINNOCK

LYNN D. TYLFR

WOI.FGANG WAWERSIK

WENDELL D. WFART

WIPP CENTRAL FILES
SARGENT \& LUNDY ENGINEERS

LAWRENCE L. HOLISH

SAVANNAH RIVER LABORATORY

E. I. HENNELIY

CAROL IANTZEN

WILLIAM R. MCDONELL

DONALD ORTH

SCANDPOWER INC

DAN POMEROY

SCIAKY BROTHERS

IOHN C. JASPER

SCIENCE APPLICATIONS INC

JEFFREY ARBITAL

JERRY J. COHEN

NADIA DAYEM

BARRY DIAL

IAMES E. HAMMELMAN

DEANC. KALU

I. ROBERT LARIVIERE

DAVID H. LESTER

PETER E. MCGRATH

IOHN E. MOSIER

HOWARD PRATT

MICHAELE. SPAEIH

M. D. VOEGELI:

KRISHAN K. WAHI

ROBERT A. YODER

SENATE RESEARCH SERVICE

DAVID WHITEHEAD

SENECA COUNTY DEPT OF PLANNINC \& DEVELOPMENT

SERIOUS TEXANS AGAINST NUCLEAR

DISPOSAL (S.T.A.N.D)

DELBERT DEVIN

SHAFER EXPLORATION COMPANY

WIILIIAM E. SHAFER

SHANNON \& WILSON INC

HARVEY'W. PARKER

SHIMIZU CONSTRUCIION COMPANY LID UINII TAKAGI

SHIMIZU CONSTRUCTION COMPANY LTD JAPAN

TAKASHIISHIII

SIERRA CLUB

MARVIN RESNIKOII

BROOKS YEAGIK

SIERRA CLUB - COLORADO OPEN SPACE

COUNCIL

ROYYOUNC:

SLICKROCK COUNTRY COUNCIL

BRIICE HULKO

LUCYK. WIALIINGIORI)

SNAKF RIVER ALIIANCE

IIM MCNEIL

SOCIETY OF PROFESSIONAL ARCHEOLOGISTS

I. M. PIERSON

SOGO IFCHNOLOGYINC IIO C. CHIN

SOUTH DAKOTA GEOLOGICAL SURVEY RI(HARD BRETY

SOUTH DAKOTA OFFICE OF ENERGY POLICY STEVEN M. WIGMAN

SOUIH DAKOIA SCHOOL OF MINES AND TECHNOLOCY

CANER ZANBAK

SOUTHERN STATES ENERGY BOARD

J. F. CIARK

NANCY KAISER

SOUTHWEST RESEARCH AND INFORMATION

CENTER

DON H HANCOCK

ALISON P. MONROI
SPRINGVILLE CITY LIBRARY

ST \& E TECHNICAL SERVICES INC

STANLEYM. KLAINER

ST. JOSEPH COLLEGE

CLAIRE MARKHAM

STANFORD UNIVERSITY

KONRAD B. KRALISKOPI

GEORGE A. PARKS

IRWIN REMSON

STATE WORKING GROUP IOHN GERVERS

STEARNS-ROGER SERVICES INC VERYL ESCHEN

STONE \& WEBSTER ENGINEERING CORP SUE NEWHAMS

IOHN H. PFCK

ARLENE C. PORT

EVERETT M. WASHER

STUDIO GEOLOGICO FOMAR - ITALY A. MARTORANA

STUDSVIK ENERGITEKNIK AB - SWEDEN ROI! SIOBIOM

SWANSON ENVIRONMENTAL INC PHIRR C. COIIINS

SWISS FEDERAL OFFICE OF ENERGY 1!. NIIDIRER

SYRACUSE UNIVERSITY WALIIR MEYER

SYSTEM DEVELOPMENT CORP RHONNIE. L. SMITH

SYSTEMS SCIENCE AND SOFTWARE PFIIRIAGILS

T.M. GATES INC IODD M. CIAILS

IECHNICAL INFORMATION PROJECT DONAIII PAY

TECHNICAL RESEARCH CENTRE OF FINLAND SIPPO VIIORI

IEKNEKRON RESEARCH INC DOUGIASK VOCII

TEXAS A \& M UNIVERSIIY SIIVE MLIRDOCK JAMIS I. RLISSL LI.

IEXAS ATTORNEY GENERALS OFFICE MICHAII. PLASTIR

TEXAS BUREAU OF ECONOMIC GEOLOGY WILIIAMI HISHIIR

TEXAS DEPT OF HEALTH DAVIDK.LACKIR

TEXAS DEPT OF WATER RESOURCES (. R. BASKIN

TEXAS ENERGY COORDINATORS OFFICE ARNULFOORII/

TEXAS GOVERNORS OFFICE OF GENERAL COUNSEL R. DANIII SMIIHI

TEXAS HOUSE OF REPRESENTATIVES HILIN SAIYIRS

TEXAS STATE HOUSE OF REPRESENTATIVES PITI. LANTY

THE ANALYTIC SCIENCES CORP JOIIN W. BARTIETT CHARLFSM. KOPLIK

THE BENHAM GROUP KIN SENOUR

THE EARTH TECHNOLOGY CORP JOSE:PH C. GIBSON

IIA VITAR

MATI WIRNER

KENNETH I. WILSON

IHE JACKSON CLARION-LEDGER MARK SCHLIFSTEIN 
TIOGA COUNTY PLANNING BOARD THOMAS A. COOKINCHAM

TRU WASTE SYSTEMS OFFICE K. V. GILBERT

TUN ISMAIL ATOMIC RESEARCH CENTRE (PUSPATI)

SAMSURDIN BIN AHAMAD

TUSKEGEE INSTITUTE

IRA G. DIILON

U.H.D.E. - W. GERMANY FRANK STEINBRUNN

U.S. BUREAU OF LAND MANAGEMENT MARY PLUMB EDWARD R. SCHERICK GREGORY F. THAYN

U.S. BUREAU OF MINES ANTHONY IANNACCHIONE

U.S. BUREAU OF RECLAMATION JOHN BROWN REGE LEACH

U.S. DEPT OF COMMERCE PETER A. RONA

U.S. DEPT OF ENERGY CHED BRADLEY R. COOPERSTEIN LAWRENCE H. HARMON CARL NEWTON IAMES TURI

U.S. DEPT OF ENERGY - ALBUQUERQUE OPERATIONS OFFICE

PHILIP LARRAGOITE IOSEPH M. MCGOUGH

U.S. DEPT OF ENERGY - CHICACO

OPERATIONS OFFICE

VICKI ALSPALGH

NURI BLIUT

GARY C. MARSHALL

PUBLIC READING ROOM

R. SELBY

U.S. DEPT OF ENERGY - CRYSTALLINE ROCK

PROJECT OFFICE

SALLY A MANN

U.S. DEPT OF ENERGY - DALLAS SUPPORT OFFICE

CURTISE. CARLSON, JR.

U.S. DEPT OF ENERGY - DIVISION OF WASTE REPOSITORY DEPLOYMENT JEFF SMILEY

U.S. DEPT OF ENERGY - GEOLOGIC

REPOSITORY DIVISION

I W. BENNETT

C. R. COOLEY $(2)$

WARREN EISTER

IIM FIORE

MARK W. FREI

CRITZH. GEORGE

RALPH STEIN

U.S. DEPT OF ENERGY - GRAND JUNCTION

OFFICE

WAYNE ROBERTS

U.S. DEPT OF ENERGY - HEADQUARTERS

PUBLIC READING ROOM

HENRY F. WALTER

U.S. DEPT OF ENERGY - IDAHO OPERATIONS

OFFICE

M. BARAINCA

CARL P. GERTZ

IAMES F. LEONARD

PUBLIC READING ROOM

J. H. SAKO

U.S. DEPT OF ENERGY - NEVADA OPERATIONS OFFJCE

PUBLIC READING ROOM
U.S. DEPT OF ENERGY - NUCLEAR WASTE POLICY ACT OFFICE IANIE SHAHEEN

U.S. DEPT OF ENERGY - NWTS PROGRAM OFFICE

J. O. NEFF

U.S. DEPT OF ENERGY - OAK RIDGE OPERATIONS OFFICE

PUBLIC READING ROOM

U.S. DEPT OF ENERGY - OFFICE OF BASIC ENERGY SCIENCES MARK W. WITTELS

U.S. DEPI OF ENFRGY - OFFICE OF DEFENSE WASTE AND BYPRODUCTS

G. K OERTEL

U.S. DEPT OF ENERGY - OFFICE OF PROJECI AND FACILITIES MANAGEMENT D. L. HARTMAN

U.S. DEPT OF ENERGY - REGION VIII SIGRID HIGDON

U.S. DEPT OF ENERGY - RICHLAND OPERATIONS OFFICE I. SCHREIBER

U.S. DEFT OF ENERGY - SAN FRANCISCO

OPERATIONS OFFICE

ENERGY RESOURCES CENTER PUBLIC READING ROOM

U.S. DEPT OF ENERGY - SAVANNAH RIVER OPERATIONS OFFICE T. B. HINDMAN

U.S. DEPT OF ENERGY - TECHNICAL

INFORMATION CENTER (317)

U.S. DEPT OF LABOR KEIVIN K. WU

U.S. DEPT OF IHF INTERIOR PAUL A. HSIEH

U.S. ENVIRONMENTAL PROTECTION AGENCY DIVISION OF CRITERIA \& STANDARDS JAMES NEIHEISEL

U.S. ENVIRONMENTAL PROTECTION AGENCY

- REGION II JOYCE FELDMAN

U.S. GENERAL ACCOUNTING OFFICE WILLIAM DAVID BROOKS

U.S. GEOLOGICAL SURVEY - ALEXANDRIA G. N. RYALS

U.S. GEOLOGICAL SURVEY - BATON ROUGE DARWIN KNOCHENMLS

U.S. GEOLOGICAL SURVEY - COLUMBUS A. M. LA SALA. JR.

U.S. GFOLOGICAL SURVEY - DENVER M. S. BEDINGER IESS M. CIIVELAND ROBERT I. HITE

U.S. GEOIOGICAL SURVEY - JACKSON GARALDG. PARKER, JR

U.S. GEOLOGICAL SURVEY - RESTON

I-MING CHOU IOHN ROBERTSON

EUCENE H. ROSEBOOM. IR DAVID B. STEWART NEWELL J. TRASK. JR

U.S. HOUSE SUBCOMMITIEE ON ENERGY AND IHE ENVIRONMENT MORRIS K. LIDALL

U.S. NATIONAL PARK SERVICE THOMAS C. WYLIF

U.S. NUCLEAR REGULATORY COMMISSION 1. CALVIN BELOTE R. BOYLE

KIEN C. CHANG

EILEEN CHEN

PATRICIA A. COMELLA
ENRICOF. CONTI

F. R. COOK

DOCKFT CONTROL CENTER

PAUL F. GOLDBERG

PHILIP S. JUSTUS

MICHAEL S. KEARNEY

MALCOLM R. KNAPP

IOHNC MCKINLEY

THOMAS J. NICHOLSON

EDWARD REGNIER

R. JOHN STARMER

MICHAEL WEBER

EVERETT A. WICK

ROBERT I. WRICHT

UINTAH COUNTY LIBRARY

UNION OF CONCERNED SCIENTISTS MICHAEL FADEN

UNITED KINGDOM DEPT OF THE ENVIRONMENT F. S. FEATES

UNIVERSITY OF AKRON LORETTA I. COLE

UNIVERSITY OF ARIZONA

IAAK DAEMEN IAMES G MCCRAY SHLOMO P. NELIMAN ROY G. POST

UNIVERSITY OF CALIFORNIA AT BERKEIEY TODD LAPORTE THOMAS H. PICFORD

UNIVERSITY OF CALIFORNIA AT LOS ANGELES D. OKRENT KRIS PRESTON

UNIVERSITY OF DELAWARE FRANK A. KULACKI

UNIVERSITY OF FLORIDA DAVID E $=$ CIARK DOLORES C. JENKINS M. J. OHANIAN

UNIVERSITY OF HAWAII AT MANOA DAVID EPP MURIIH MANGHNANI

UNIVERSITY OF ILLINOIS AT URBANA CHA UPAIGN

DANIEL F. HANG MAGDI RAGHE

UNIVERSITY OF MARYLAND FRANK J. MLINNO MARVIN ROUSH

UNIVERSITY OF MICHIGAN WILLIAM KERR

UNIVERSITY OF MINNESOTA CHARLFS FAIRHIIRST DONALD GILLIS RAYMOND STERIING

UNIVERSITY OF MISSISSIPPI GEORGE D. BRUNTON

UNIVERSITY OF MISSOURI AT KANSAS CITY EDWIN D. GOEBEL SYEDE. HASAN

UNIVERSITY OF MISSOURI AT ROLLA ALLEN W. HATHEWAY ARVIND KUMAR NICK TSOULFANIDIS

UNIVERSITY OF NEW MEXICO HAROLDM ANDFRSON DOUGLAS G. BROOKINS RODNEY C. EWING

UNIVERSITY OF OKLAHOMA DANIEL T. BOATRIGHT

UNIVERSITY OF OTTAWA - CANADA TUNCER OREN 
Neelameghan, A., 1979. "Expressions of Time in Information Science and Their Implications", Time and the Sciences, Frank Greenaway, ed., Unesco, Paris, France, pp. 103-118.

Panofsky, Dora, and Erwin Panofsky, 1962. Pandora's Box: The Changing Aspects of a Mythical Symbol, Bollingen Series LII, Pantheon, New York, NY.

Rifkin, Jeremy, 1980. Entropy: A New World View, Viking Press, New York, NY.

Sebeok, Thomas A., 1976. Contributions to the Doctrine of Signs, Peter de Ridder Press, Lisse, Netherlands.

Uexku11, Jakob von, 1980. Kompositionslehre der Natur, Ullstein, Frankfurt am Main, FRG.

U.S. Nuclear Regulatory Commission, 1983. "Disposal of High-Level Radioactive wastes in Geologic Repositories, Technical Criteria", 10 CFR Part 60, Federal Register, (48 FR 28194), Washington, DC, June 21.

Wiener, Norbert, 1950. The Human Use of Human Beings: Cybernetics and Society, Houghton Mifflin, Boston, MA.

Winograd, Isaac J., 1981. "Radioactive Waste Disposal in Thick Unsaturated Zones", Science, No. 212, pps. 1457-1464. 
UNIVIEERITY OF PITTSBURGH

B. L. COHEN

UNIVERSITY OF SOUTHERN MISSISSIPPI CHARLES R. BRENT JAMES W. PINSON

UNIVERSITY OF TEXAS AT AUSTIN PAUL ANAEIIONU BUREAU OF ECONOMIC GEOLOGY EARNEST F. GLOYNA THOMAS C. GUSTAVSON MARTIN P. A. JACKSON JOE O. LEDBETTER E. G. WERMUND UNIVERSITY OF TEXAS AT SAN ANTONIO DONALD R. LEWIS

UNIVERSITY OF TOKYO - IAPAN RYOHEI KIYOSE

UNIVERSITY OF TORONTO - CANADA N. S. BRAR

UNIVERSITY OF UTAH

JAMES W. BUNCER

MARRIOTT LIBRARY

GARYM. SANDQUIST

UNIVERSITY OF WASHINGTON M. A. ROBKIN

UNIVERSITY OF WISCONSIN B. C. HAIMSON

UNIVERSITY OF WISCONSIN AT MILWAUKEE HOWARD PINCUS

UPPER PEASE SOIL AND WATER

CONSERVATION DISTRICT W.H. MARSHALL

URS-BERGER TONY MORGAN

URS/JOHN A. BLUME \& ASSOCIATES,

ENGINEERS ANDREW B. CUNNINGHAM

UTAH DEPT OF NATURAL RESOURCES \& ENERGY

MARK A. PAGE

UTAH DEPT OF TRANSPORIATION DELOY K. PETERSON
UTAH DIVISION OF ENVIRONMENIAL HEALIH MARV H. MAXELL

UTAH DIVISION OF OIL, GAS \& MINING SALLY J. KEFER

UTAH DIVISION OF PARKS \& RECREATION JOHN KNUIDSON GORDON W. TOPHAM

UTAH ENERGY OFFICE ROD MILLAR

UTAH ENVIRONMENT CENTER JUNE WICKHAM

UTAH GEOLOGICAL AND MINERAL SURVEY GENEVIEVE ATWOOD BILL LLIND MAGE YONETANI

UTAH OFFICE OF PLANNING \& BUDGET RANDY MOON $\{25\}$

UTAH SOUTHEASTERN DISTRICT HEALIH DEPARTMENT ROBERT L. FURLOW

UTAH STATE GEOLOGIC TASK FORCE DAVID D. TILLSON

UTAH STATE UNIVERSITY IACK T. SPENCE

UTAHNS ACAINST THE DUMP COALITION

UTILITY DAIA INSTITUTE FRED YOST

VANDERBILT UNIVERSITY FRANK L. PARKER

VEPCO B. H. WAKEMAN

VERMONT DEPT OF WATER RESOURCES AND ENVIRONMENIAL ENGINEERING CHARIES A. RATIE

VERMONT STATE NUCLEAR ADVISORY PANEL VIRGINIA CALLAN

VIRGINIA DEPT OF HEALIH

WILLIAM F. GILLEY ROBERT C. WICKLINE

VIRGINIA DIVISION OF MINERAL RESOURCES ROBERT C. MILICI
VIRGINIA HOUSE OF DELEGAIES

A. IICIOR IHONIAS

VIRGINIA POLYTECHNICAL INSTITUTE AND STATE UNIVERSITY GARY I. DOWNEY

WA STAIE DEPARTMENT OH ECOLOGY DAVID W. SIIVINS

WASHING ION DEPI OF SOCIAL AND HEALIH SERVICES T. STRONG;

WASHINGION HOUSE OF REPRESENTATIVES RAY ISAACSON

WATTLAB BOB F. WAII

WEBSTER PARISH LIBRARY

WEST VALIFY NUCLEAR SERVICES CO INC CHRIS CHIAPAIAN IRICHII. MAYTR

WESTERN SIATE COLLEGE IRID) R. PI ( $K$

WESTINGHOUSE ELECTRIC CORP CiIORGII B. HAOII IAMILPH. SALING: IANHSR YCHORNHOI

WIPP PROJECI

MISIINCIHCO'SH HILIRIC CORPORAIION

WISCONSIN DIVISION OF STATE ENERGY ROBIRI HIALSIIAII

WOODS ROBER ISON ASSOCIAIES - CANADA WOODWARD-CLYDE CONSULTANTS

F. R. CONWIIL. (2)

TIRRY A. GIRANI

ASHOR PAIWARIJHAN

WISII RN RIGION IIBRARY

WP-SYSTEM AB - SWEDEN IVAR SAGLIORS

WRIGHT STATE UNIVERSITY MICHAEL I ARRIII.

YALE UNIVERSITY

G. R. HOIIMAN 